\title{
On the Other Side of Viruses in the Background of Water Disinfection
}

\author{
Djamel Ghernaout ${ }^{1,2 *}$, Noureddine Elboughdiri1,3 \\ ${ }^{1}$ Chemical Engineering Department, College of Engineering, University of Ha'il, Ha'il, KSA \\ ${ }^{2}$ Chemical Engineering Department, Faculty of Engineering, University of Blida, Blida, Algeria \\ ${ }^{3}$ Département de Génie Chimique de Procédés, Laboratoire Modélisation, Analyse, et Commande des systèmes, Ecole Nationale \\ d’Ingénieurs de Gabès (ENIG), Rue Omar Ibn-Elkhattab, Gabès, Tunisia \\ Email: *djamel_andalus@hotmail.com
}

How to cite this paper: Ghernaout, D. and Elboughdiri, N. (2020) On the Other Side of Viruses in the Background of Water Disinfection. Open Access Library Journal, 7: e6374.

https://doi.org/10.4236/oalib.1106374

Received: April 29, 2020

Accepted: May 18, 2020

Published: May 21, 2020

Copyright $\odot 2020$ by author(s) and Open Access Library Inc.

This work is licensed under the Creative Commons Attribution International License (CC BY 4.0).

http://creativecommons.org/licenses/by/4.0/

\begin{abstract}
At COVID-19 time, as surface water and urban wastewater will constantly carry microbial pathogens, pathogens should be eliminated at least to degrees that do not have an effect on public health. Among the pathogen groups observed in water, viruses constitute the biggest danger since they frequently appear in much bigger levels and possess much greater infectivity than bacteria and parasitic protozoa. This work highlights the viruses especially in terms of composition and behavior in ecosystems and discusses the main disinfection techniques, especially thermal demobilization, chlorination and ozonation, and their involved mechanisms. Precise estimates of viral demobilization and log removal throughout water treatment techniques stay crucial for evaluating danger to human health, developing regulations, and informing engineering design of full-scale treatment plants. Practical demobilization details developed at bench-scale for human pathogens like norovirus and COVID-19 will be vital. The more we study the composition of viruses and their fate in ecosystems, and the more we try the techniques for their disposal in water treatment plants, the more we realize that it is difficult to get rid of them using a single treatment method. Employing advanced water treatment trains (such as coagulation, reverse osmosis, ultrafiltration, advanced oxidation) was proposed to guarantee removals of viruses to differing degrees of regulatory control following the degrees of human subjection and related health hazards.
\end{abstract}

\section{Subject Areas}

Chemical Engineering \& Technology, Public Health

\section{Keywords}

Viruses, Disinfection, Virology, Thermal Inactivation, Chlorination, Ozone 


\section{Introduction}

The study of viruses, virology, is comparatively young [1]. Following written descriptions of disease or from the investigation of mummies with specific abnormalities, particular viruses are viewed as the causative agents of epidemics that happened hundreds or thousands of years ago. In addition, immunization against smallpox has been practiced for more than a millennium. Nevertheless, it was only around 110 years ago that viruses were depicted to be filterable and thus different from bacteria that provoke infectious diseases. It was only around 70 years ago that the composition of viruses was defined, and even more recently before they could be seen as particles in the electron microscope. During the previous three decades, nevertheless, the development of current biotechnology has driven to an outstanding expansion in the comprehension of viruses and their interactions with their hosts. Virology comprises several features: the molecular biology of virus replication; the structure of viruses; the interactions of viruses and hosts and the diseases they engender in those hosts; the evolution and history of viruses and viral diseases; virus epidemiology, the ecological niche occupied by viruses and how they spread from victim to victim; and the prevention of viral disease by vaccination, drugs, or other methods. The domain is large and any treatment of viruses must perforce be selective [1].

Viruses are recognized to infect most organisms, involving bacteria, blue-green algae, fungi, plants, insects, and vertebrates; however, the focus is accorded here to present a general review on virology that underlines their capability as human disease agents [1]. Due to the field of virology, and due to human viruses that provoke diseases, particularly epidemic diseases, are not uniformly distributed across virus families, the discussion is not intended to be comprehensive. Even so, it is crucial that the human viruses be introduced in the viewpoint of viruses as a whole so that some overall understanding of this fascinating group of agents can emerge. Thus, we consider many nonhuman viruses that are important for our understanding of the evolution and biology of viruses [1].

\section{Viruses Provoke Disease (But Are Also Helpful as Tools)}

Viruses remain of extreme attention since numerous provoke grave illness in humans or domestic animals, and others harm crop plants. During the previous century, advance in controlling infectious diseases via ameliorated sanitation, safer water supplies, the expansion of antibiotics and vaccines, and better medical care have greatly decreased the menace to human health and life from such agents, particularly in poor countries. This is shown in Figure 1, in which the death rate from infectious disease in the US throughout the previous century is illustrated. At the beginning of the twentieth century, $0.8 \%$ of the population died each year from infectious diseases. Today, the rate is less than one-tenth as great. Employing vaccines has driven to efficient control of the most hazardous of the viruses. Smallpox virus has been destroyed completely throughout the world via procedures of an ambitious and concerted effort, sponsored by the 


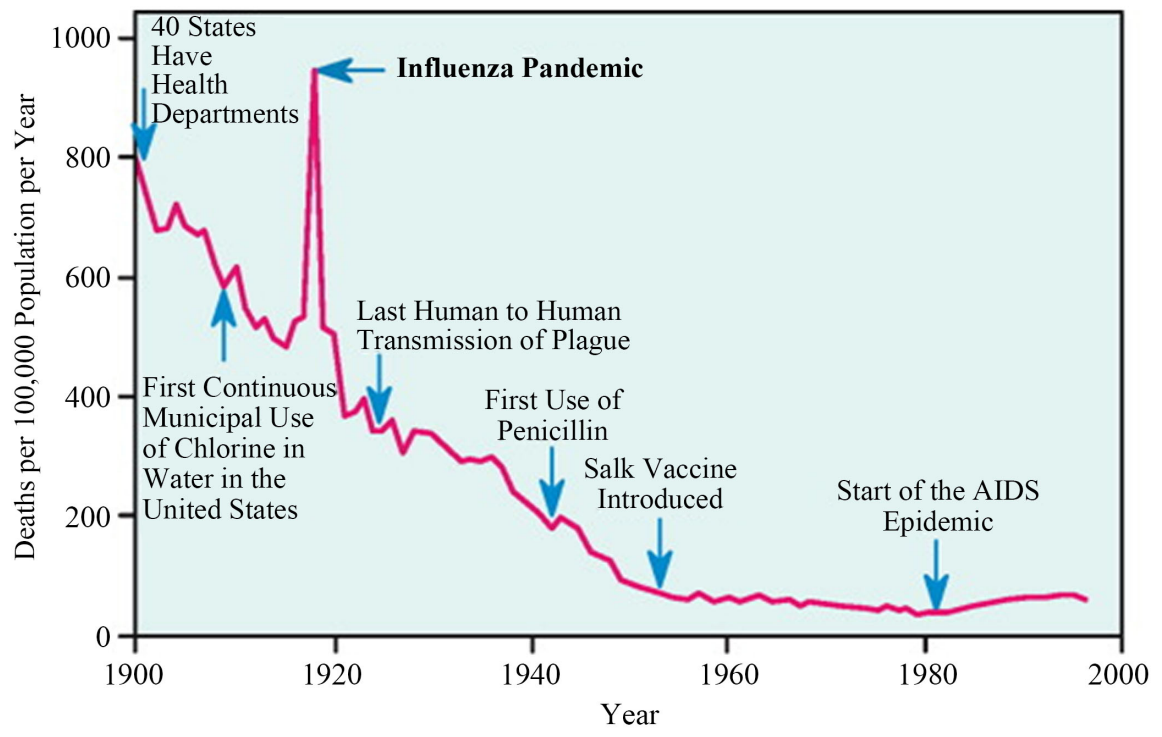

Figure 1. Death rate from infectious diseases in the US, 1900-1996. The death rate dropped over the $20^{\text {th }}$ century from around 800 deaths per 100,000 population per year to about 50. Significant milestones in public health are shown. After dropping steadily for 80 years, interrupted only by the influenza pandemic of 1918-1919, the death rate began to rise in 1980 with the advent of the AIDS (acquired immunodeficiency syndrome) epidemic [1].

World Health Organization (WHO), to vaccinate all people at risk for the disease. Poliovirus and measles virus have been eradicated from the Americas through large vaccination programs. There is a hope that such two viruses will as well be removed worldwide in the near future. Vaccines exist for the control of several other viral diseases comprising, among others, mumps, rabies, rubella, yellow fever, Japanese encephalitis, rotaviral gastroenteritis, and, very lately, papillomavirus disease that is the first cause of cervical cancer [1].

The spectacular drop in the death rate from infectious diseases has driven to a particular level of self-satisfaction. There is a little but vocal trend in the US and Europe to terminate immunization against viruses, for instance. Nevertheless, viral diseases persist to plague humans, as do infectious diseases generated by bacteria, protozoa, fungi, and multicellular parasites. Deaths worldwide because of infectious diseases are illustrated in Figure 2, classified into six groups. In 2002 more than 3 million deaths happened as a consequence of acute respiratory disease, much of which is induced by viruses. More than 2 million deaths were due to diarrheal diseases, about half of which are due to viruses. In the same year, AIDS killed 3 million people worldwide, and measles stay a notable killer in poor nations. Realization is increasing that infectious diseases, of which viruses form a major component, have not been defeat via the introduction of vaccines and drugs. Viral diseases and diseases triggered by other pathogens push along to endure elimination. On the other hand, the overutilization of antibiotics has conducted to an upsurge in antibiotic-resistant bacteria, which has exacerbated the issues provoked by them [1] [2] [3] [4]. 


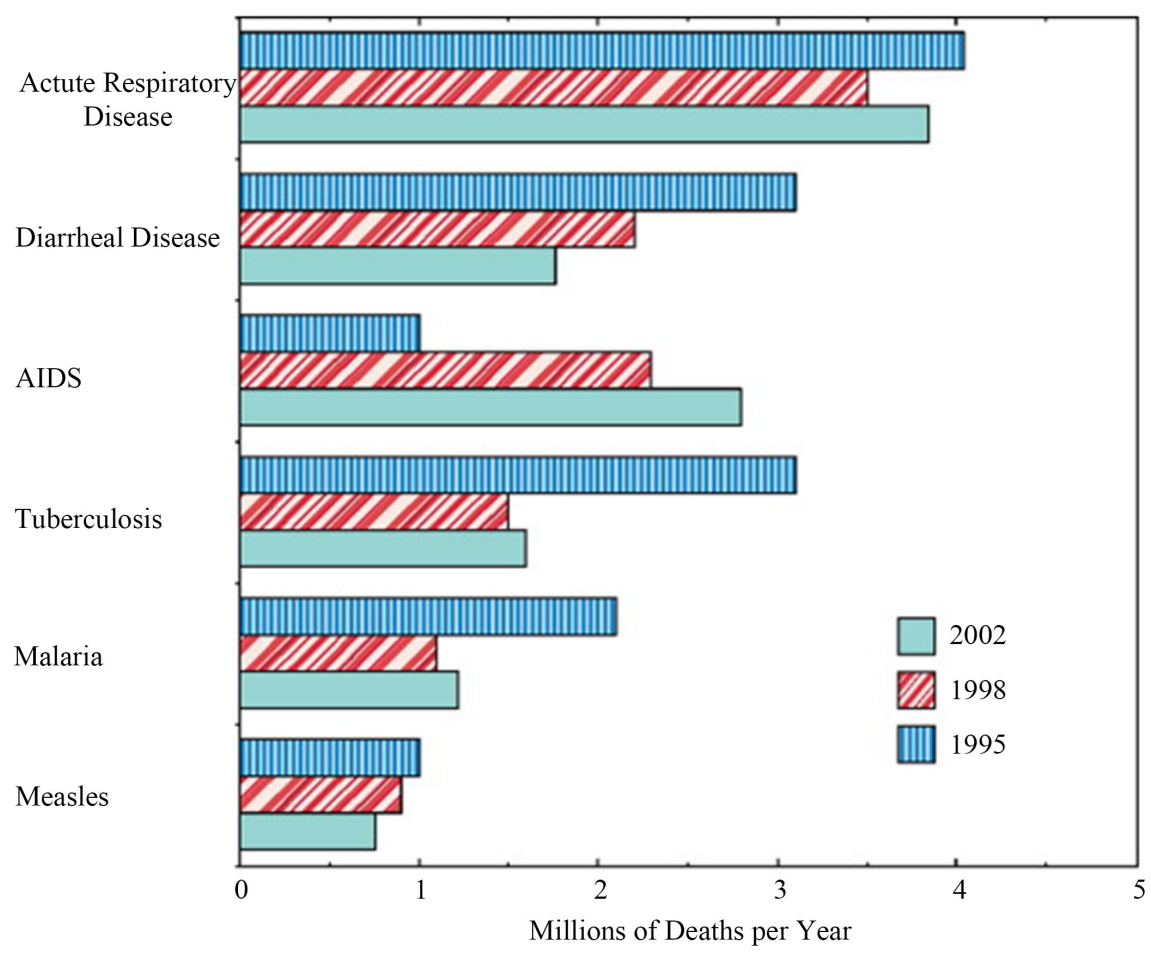

Figure 2. Six leading infectious diseases as causes of death. Data are the totals for all ages worldwide in 1995, 1998, and 2002 [1].

The happening of disease in different regions of the earth provoked by some widespread viruses is shown in Figure 3. For most viruses, in the Americas and Europe, widespread usage of vaccines has almost removed disease formed by viruses for which vaccines exist. In poor countries, measles, poliovirus, yellow fever virus, and rabies virus, as well as others not illustrated in the figure, still generate grave problems even if good vaccines exist. Nevertheless, developed countries, as well as poor countries, suffer from viruses for which no vaccines exist to the present time. Human immunodeficiency virus (HIV), shown in the figure, is a case in point [1].

The perseverance of viruses is partially attributed to their capacity to mutate quickly and adjust to novel circumstances [1]. HIV is the most noticeable example of the release of a virus that has lately entered the human population and provoked a plague of universal significance. The appearance of such a virus in the US produced a remarkable augmentation in the total number of deaths from infectious diseases (Figure 1). Moreover, formerly undiscovered viruses also persist to come out as hazardous pathogens. Sin Nombre virus, a formerly obscure virus related to rodents, triggered a 1994 eruption in the US of Hantavirus pulmonary syndrome with a $50 \%$ case fatality rate, and it is now known as being general in North America. Junin virus, the source of Argentine hemorrhagic fever, as well as of the same family viruses, has become a more dangerous problem in South America with the prevalence of farming. Ebola virus, in charge of numerous small African epidemics with a case fatality rate of $70 \%$, was first 


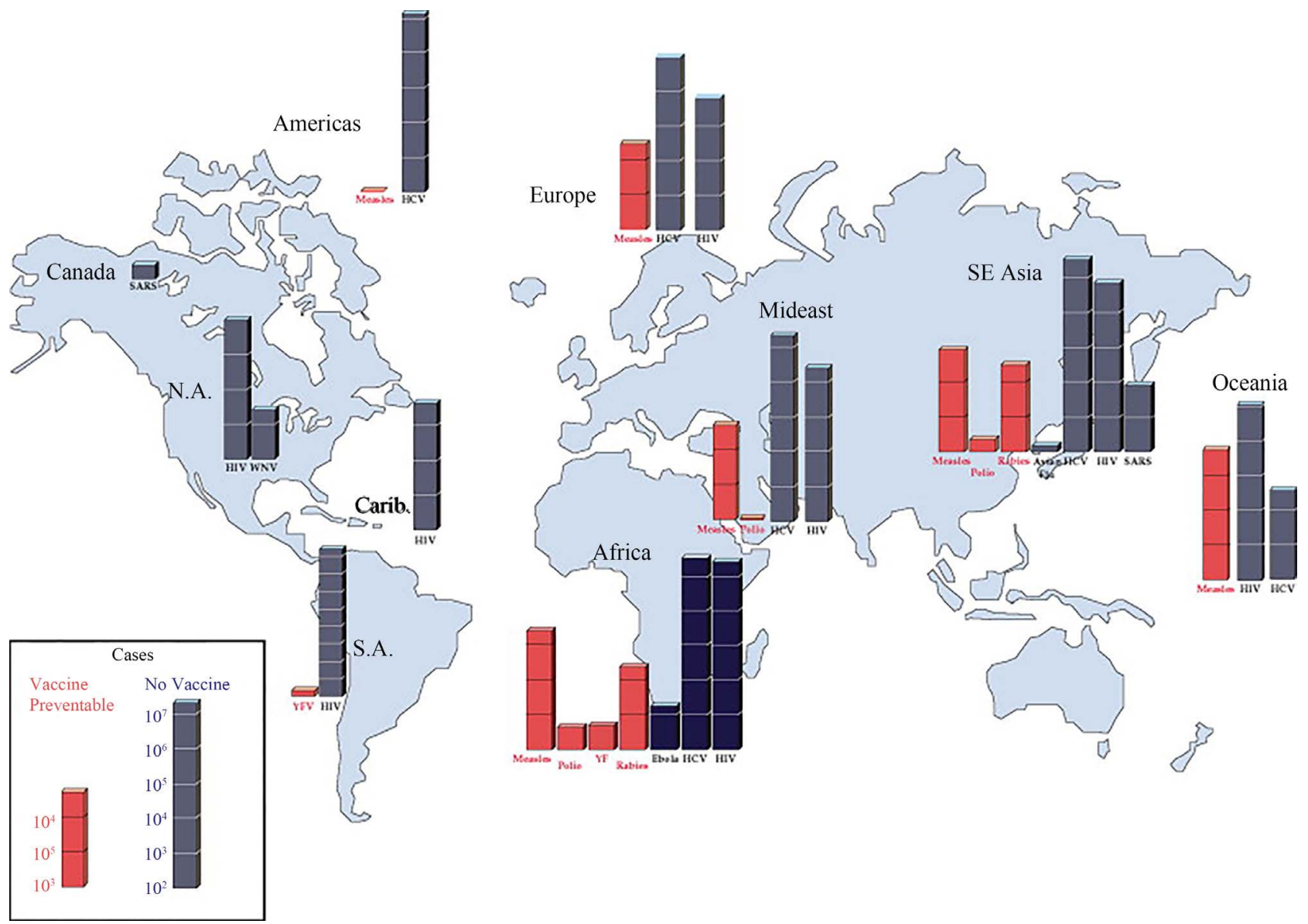

Figure 3. Incidence of selected infectious diseases worldwide and the effect of vaccination. The number of cases is shown on a log scale such that each division represents 10 -fold more cases than the division below it. The diseases for which vaccines exist are shown in red (SARS, severe acute respiratory syndrome; HIV, human immunodeficiency virus; WNV, West Nile virus; YFV, yellow fever virus; $\mathrm{HCV}$, hepatitis $\mathrm{C}$ virus) [1].

discovered in the 1970s [1]. Nipah virus, a formerly strange virus of bats, manifested in 1998 and led to 258 cases of encephalitis, with a 40\% fatality rate, in Malaysia and Singapore. The SARS virus, also a formerly obscure virus of bats, conducted to an epidemic that killed more than 700 humans worldwide in 2002-2003. The H5N1 strain of influenza, known as "bird flu," has killed more than 150 humans in the last few years and there is fear that it might eventually cause a worldwide pandemic with hundreds of millions of deaths. It is evident that the risk for the fast diffusion of all viruses is augmenting as faster and more global travel becomes ever more routine. The hazard stays that any of such viruses could become more diffuse, as has HIV since its appearance in Africa perhaps half a century ago, and as has West Nile virus, which spread to the Americas in 1999.

Freshly surfacing viruses are not the only ones to plague humans [1]. Indeed, several viruses that have been studied for a long period persist to rise extensive troubles. As an illustration, the respiratory syncytial virus remains a large cause of pneumonia in infants. Despite numerous endeavors, it has not yet been feasi- 
ble to present an efficient vaccine. Surprisingly when vaccines exist, issues could persist. For instance, the influenza virus mutates quickly and the vaccine for it should be redeveloped ever year. Since the main source for influenza is birds, it is not conceivable to eliminate the virus. Therefore, to dominate influenza would need that the complete population is immunized ever year. This is a difficult issue and the virus persists to form annual epidemics with a considerable death rate. Although primarily a killer of the elderly, the potential of influenza to kill the young and healthy was shown by the worldwide epidemic of influenza in 1918 in which 20 - 100 million people died worldwide.

On the other hand, viruses have been helpful in investigating molecular and cellular biology [1]. Then, the emergence of viruses as vectors for the expression of foreign genes has given them a novel and extended contribution in science and medicine, comprising their possible usage in gene therapy. Several Nobel Prizes have been granted in recognition of considerable progress in biological science that given rise to researches that implicated viruses (Table 1). As an illustration, Max Delbrück received the prize for pioneering researches in what is now named molecular biology, employing bacteriophage T4. Cellular oncogenes were first lighted on from their occurrence in retroviruses that could transform cells in culture, a discovery that resulted in a prize for Francis Peyton Rous for his discovery of transforming retroviruses, and for Michael Bishop and Harold Varmus, for showing that a transforming retroviral gene had a cellular counterpart [1].

\section{Nature of Viruses}

Viruses are subcellular, infectious agents that are obligate intracellular parasites. They infect and take over a host cell in order to replicate. The mature, extracellular virus particle is called a virion. The virion contains a genome that may be DNA or RNA wrapped in a protein coat called a capsid or nucleocapsid. Some viruses have a lipid envelope surrounding the nucleocapsid (they are "enveloped").

Table 1. Pathways of demobilization employed via frequent disinfectants [5] [14].

\begin{tabular}{|c|c|c|}
\hline Target & Agent & Impact \\
\hline \multirow{2}{*}{ Cell wall } & Aldehydes & Interaction with $-\mathrm{NH}_{2}$ groups \\
\hline & Anionic surfactants & Lysis \\
\hline Cytoplasmic membrane & $\begin{array}{l}\text { Quaternary ammonium compounds, } \\
\text { biguanides, hexachlorophene }\end{array}$ & $\begin{array}{l}\text { Leakage of low molecular weight } \\
\text { material }\end{array}$ \\
\hline Nucleic acids & $\begin{array}{l}\text { Dyes, alkylating agents, ionizing and } \\
\text { ultraviolet radiation }\end{array}$ & $\begin{array}{l}\text { Breakage of bonds, cross-linking, } \\
\text { binding of agents to nucleic acids }\end{array}$ \\
\hline \multirow[b]{3}{*}{ Enzymes or proteins } & Metal ions (Ag, Cu) & Bind to $-\mathrm{SH}$ groups of enzymes \\
\hline & Alkylating agents & Combine with DNA or RNA \\
\hline & $\begin{array}{l}\text { Oxidizing agents (chlorine, hydrogen } \\
\text { peroxide) }\end{array}$ & $\begin{array}{l}\text { Damage of bacterial cell } \\
\text { membranes; damage of proteins } \\
\text { and nucleic acid }\end{array}$ \\
\hline
\end{tabular}


In such viruses, glycoproteins encoded by the virus are embedded in the lipid envelope. The function of the capsid or envelope is to protect the viral genome while it is extracellular and to promote the entry of the genome into a new, susceptible cell [1].

The nucleic acid genome of a virus carries the details requested by the virus to replicate and form fresh virions following its introduction into a susceptible cell. Virions bind to receptors on the surface of the cell, and by some processes, it is liberated into the cytoplasm of the cell, sometimes still in association with protein ("uncoating"). The genome then redirects the cell to the replication of itself and to the production of progeny virions. The cellular machinery that is in place for the production of energy (synthesis of ATP) and for macromolecular syntheses, such as translation of mRNA to produce proteins, is essential [1].

It is helpful to think of the proteins encoded in viral genomes as belonging to three major classes [1]. First, most viruses encode enzymes required for replication of the genome and the production of mRNA from it. RNA viruses must encode an RNA polymerase or replicase, since cells do not normally replicate RNA. Most DNA viruses have access to the cellular DNA replication machinery in the nucleus, but even so, many encode new DNA polymerases for the replication of their genomes. Even if they use cellular DNA polymerases, many DNA viruses encode at least an initiation protein for genome replication.

\section{Disinfection}

The demolition or prevention of the development of pathogens remains fundamental for dominating infectious disease transmission and keeping foodstuffs and biodegradable materials [5] [6]. This is usually performed via heating, chemical injection, filtration or radiation [7]. Heat works to neutralize or demobilize via denaturation of vital proteins (enzymes, viral capsids) and nucleic acids. Chemical products could perform through several fashions to neutralize microbes or avoid their development, comprising the demolition of membranes and cell walls, and interference with enzymic action and replication of nucleic acids (Table 1). Filtration is a method that works to retain the bacteria physically via size exclusion and does not lead to the demolition of the pathogenic microorganisms [8] [9] [10]. Ultraviolet (UV) light and gamma radiation take action directly on nucleic acids [5] [11] [12] [13].

Physically or chemically, sterilization is a method that demolishes or removes all microorganisms [5]. A sanitizer is an agent that decreases the number of bacterial pollutants to safe degrees as decided by public health requirements. Following the official sanitizer test employed in the US, a sanitizer is a chemical that neutralizes $99.9 \%$ of the particular test bacteria during $30 \mathrm{~s}$ below the circumstances of the test [14]. Physically or chemically, a disinfectant is an agent that demolishes disease-causing or other dangerous microorganisms; however, it does not necessarily neutralize all microorganisms [15] [16]. Disinfectants are anticipated to neutralize more than $99.999 \%$ of the test organisms [17] [18]. 
Disinfectants are frequently implemented to water and inanimate objects (fomites) to dominate the diffusion of pathogenic microorganisms. They may as well be utilized to treat foods and aerosols. A bacteriostat is commonly a chemical agent that blocks the development of bacteria; however, it does not necessarily neutralize them. As an illustration, silver is frequently added to activated carbon to stop the development of bacteria in home faucet-mounted water treatment devices [5] [19] [20] [21] [22].

\subsection{Thermal Demolition}

Demolishing microbes thermally has been examined in extensive pieces of information by the food industry due to the significance of such a technique in killing pathogenic bacteria and blocking foodborne spoilage. The thermal death of microorganisms is frequently viewed as a first-order relationship (that is to say, linear with time). The period requested to neutralize a specific number of organisms at a particular temperature is named the thermal death time (TDT). To estimate TDT, the usual manner is to place a known number of organisms in a sufficient number of sealed containers to get the desired number of survivors for the test period. At the end of the heating period, the containers are quickly removed and cooled in cold water. The viability of the organisms is evaluated on standard culture media [5].

The TDTs of some foodborne and waterborne pathogens are listed in Table 2. The $D$ value or decimal reduction time is the period needed to demolish $90 \%$ of the organisms. This value is numerically equal to the number of minutes requested for the survivors as a function of the time curve to traverse one log (Figure 4). This is equal to the reciprocal of the slope of the survivor curve and it

Table 2. Thermal death times (TDTs) of water- and food-borne pathogenic organisms [5].

\begin{tabular}{cc}
\hline Microorganism & Temperature $\left({ }^{\circ} \mathrm{C}\right) /$ time $(\mathrm{min})$ \\
\hline Campylobacter spp. & $75 / 1$ \\
Escherichia coli & $65 / 1$ \\
Legionella & $66 / 0.45^{a}$ \\
Mycobacterium spp. & $70 / 2$ \\
Mycobacterium avium & $70 / 2.3^{a}$ \\
Salmonella spp. & $65 / 1$ \\
Shigella spp. & $65 / 1$ \\
Vibrio cholerae & $55 / 1^{a}$ \\
Cryptosporidium parvum & $72.4 / 1$ \\
Giardia lamblia & $50 / 1^{a}$ \\
Hepatitis A virus & $70 / 10$ \\
Rotavirus & $50 / 30$ \\
\hline
\end{tabular}

${ }^{a}$ In buffered distilled water. 


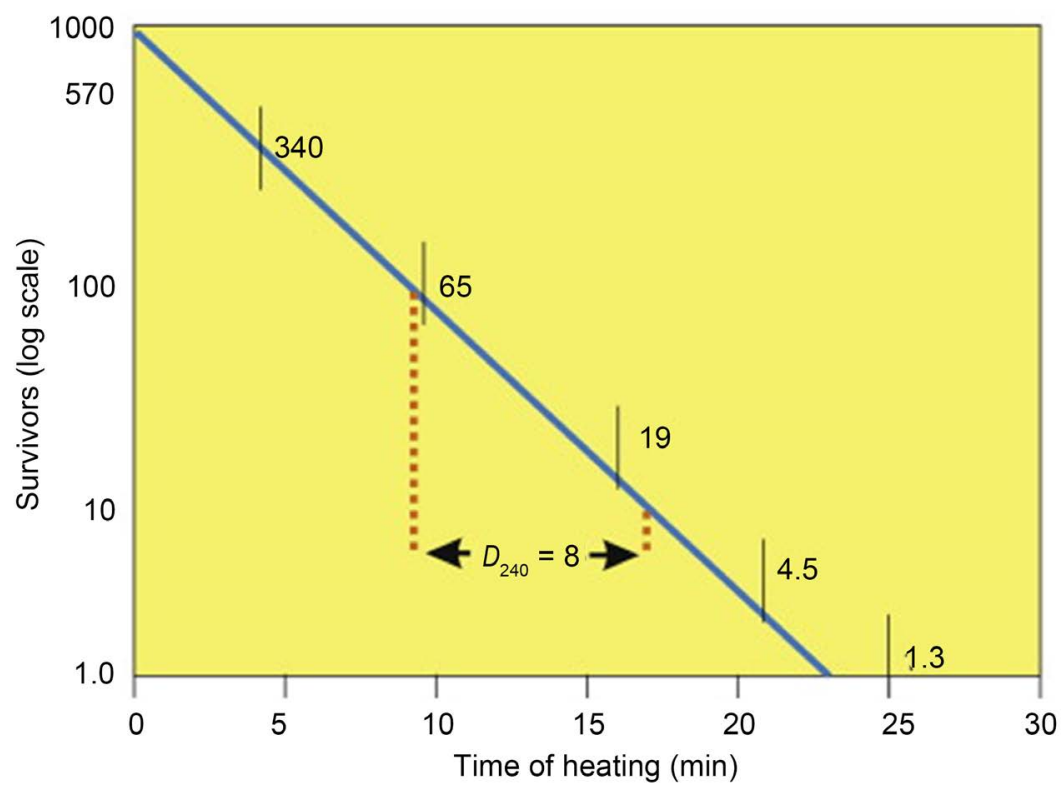

Figure 4. Thermal inactivation curve for a microorganism. The $D$ value is the period requested for demobilization of $90 \%$ of the microorganisms at a specific temperature. In this case, it needed $8 \mathrm{~min}$ to neutralize $90 \%$ of the microorganisms at $240^{\circ} \mathrm{F}\left(115^{\circ} \mathrm{C}\right)$ or $D_{240}=8 \min [5]$.

is a measure of the death rate of an organism. The temperature, at which the $D$ value is estimated, is given as a subscript [5]. As an illustration, the $D$ value for Clostridium perfringens at $250^{\circ} \mathrm{F}\left(121^{\circ} \mathrm{C}\right)$ is $D_{250}=0.1$ to 0.2 [23]. The $z$ value refers to the degrees Fahrenheit requested for the thermal destruction as a function of the temperature curve to traverse one log. This value is equal to the reciprocal of the slope of the TDT curve (Figure 5). While $D$ reflects the resistance of an organism to a particular temperature, $z$ furnishes detail on the relative resistance of an organism to various destructive temperatures; it permits the determination of equivalent thermal processes at distinct temperatures. If, for instance, $3.5 \mathrm{~min}$ at $140^{\circ} \mathrm{F}\left(60^{\circ} \mathrm{C}\right)$ is considered to be an adequate process and $z=$ 8.0 , either $0.35 \mathrm{~min}$ at $148^{\circ} \mathrm{F}\left(64^{\circ} \mathrm{C}\right)$ or $35 \mathrm{~min}$ at $132^{\circ} \mathrm{F}\left(55^{\circ} \mathrm{C}\right)$ would be considered equivalent processes [5].

Spore-forming microbes like Bacillus and Clostridium are the most resistant to heat demobilization [5]. Of the nonspore-forming waterborne and foodborne enteric pathogens, enteric viruses are the most heat resistant, followed by the bacteria and protozoa (Table 2). Parvoviruses are among the most heat-resistant viruses known [24]. In addition to the type of microorganism, factors that affect TDT in foods comprise water, fat, salts, sugars, $\mathrm{pH}$ and other substances. The heat resistance of microbial cells augments with reducing humidity or moisture. Dried microbial cells are greatly more heat resistant than moist cells of the same type. Because protein denaturation happens at a higher rate with heating in water than in air, it is probable that protein denaturation is closely associated with thermal death.

The occurrence of fats and salts augments the heat resistance of numerous 


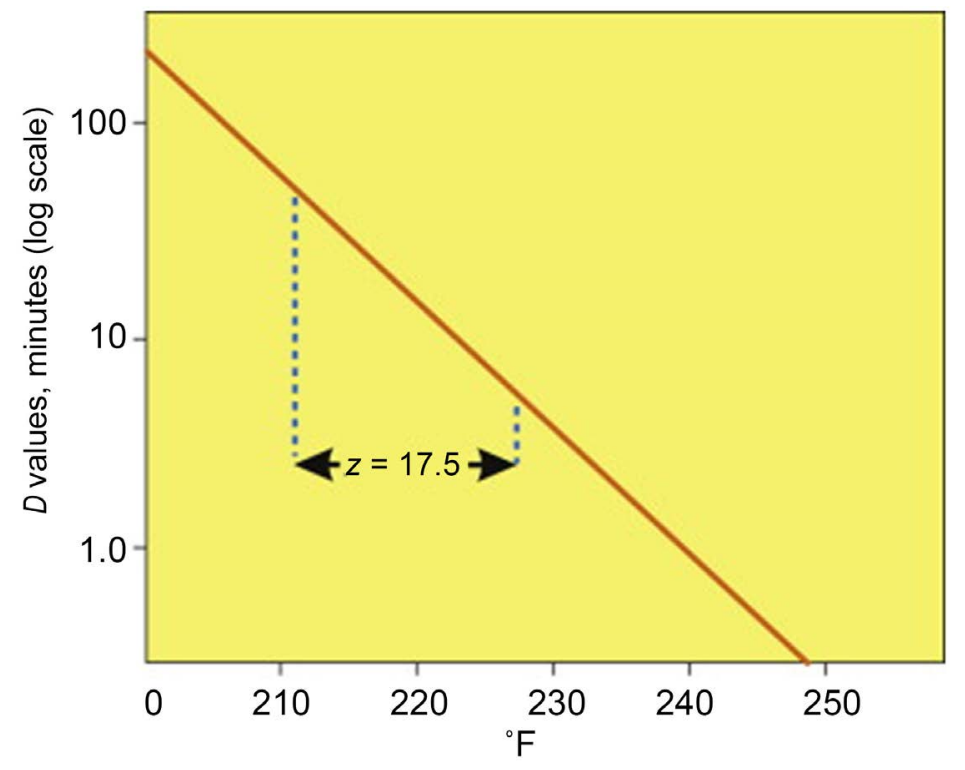

Figure 5. Thermal death time (TDT) curve. The $z$ value is equal to the degrees Fahrenheit needed for the thermal demolition curve to traverse one log cycle [5].

microbes. The influence of salt is varying and following the type of salt, concentration, and cation [5]. Cationic salts at molar concentrations considerably augment the thermal resistance of enteric viruses. For such cause, $\mathrm{MgCl}_{2}$ is added to the poliovirus vaccine to aid in lengthening its useful life. The occurrence of sugars provokes an elevation in the heat resistance of microbes, partially due to reduced water activity. Microbes are most resistant to heat at their optimal $\mathrm{pH}$ of growth, which is frequently around 7.0. Since the $\mathrm{pH}$ is reduced or augmented from the optimal degree, there is an elevation in heat sensitivity. Consequently, acid and alkaline foods need less heat processing than neutral foods. In water, suspended solids or organic matter elevate heat resistance [25].

\subsection{Kinetics of Disinfection}

Demobilizing microbes is a progressive operation that implicates a chain of physicochemical and biochemical stages. Numerous models have been proposed on the basis of empirical facts. The leading disinfection theory employed until now stays the Chick-Watson model, which expresses the rate of demobilization of microbes via a first-order chemical reaction [5] [7]:

$$
N_{t} / N_{0}=e^{-k t}
$$

or

$$
\ln N_{t} / N_{0}=-k t
$$

where:

$N_{0}=$ number of microorganisms at time $0 ; N_{\mathrm{t}}=$ number of microorganisms at time $t, k=$ decay constant ( $1 /$ time), and $t=$ time.

The logarithm of the survival rate $\left(N_{\mathrm{t}} / N_{0}\right)$ plots as a straight line versus time (Figure 6). Laboratory and field details frequently deviate from first-order kinetics. 


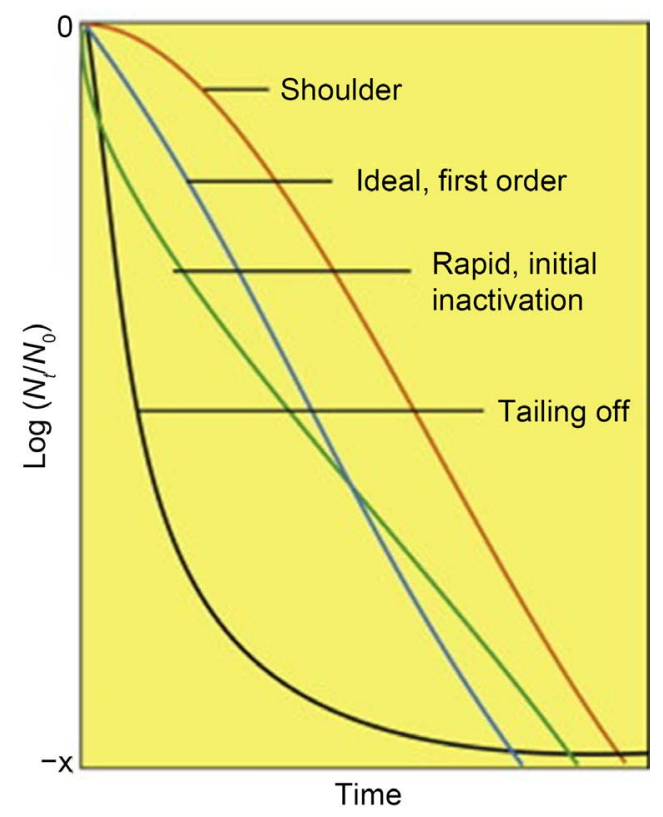

Figure 6. Sorts of demobilization curves detected for microorganisms [5].

Shoulder curves could follow from clumps of organisms or multiple hits of critical sites before demobilization. Curves of such sort are usual in the disinfection of coliform bacteria via chloramines [7] [26] [27] [28]. The tailing-off curve, commonly observed with several disinfectants, can be interpreted through the survival of a resistant subpopulation as a consequence of protection by interfering substances (suspended matter in water), clumping or genetically conferred resistance [5] [7] [29].

In water utilization, disinfectant performance could be expressed as $C t$, where $C$ is the disinfectant concentration and $t$ the time needed to demobilize a certain percentage of the population below particular circumstances $(\mathrm{pH}$ and temperature). Usually, a degree of $99 \%$ demobilization is utilized when juxtaposing $C t$ estimates. The lower the $C t$ value, the more efficient the disinfectant. The $C t$ method lets a global differentiation of the efficacy of divers disinfectants on different microbial agents (Table 3). It is employed by the drinking water industry to evaluate how many disinfectants must be applied during treatment to achieve a given reduction in pathogenic microorganisms. $C t$ values for chlorine for a variety of pathogenic microorganisms are shown in Table 3. The order of resistance to chlorine and most other disinfectants used to treat water is protozoan cysts $>$ viruses $>$ vegetative bacteria [5].

\subsection{Elements Influencing Disinfectants}

Several elements regulate the efficiency and/or rate of neutralizing a specific pathogen (Figure 7). Temperature possesses a main influence since it masters the rate of chemical reactions. Therefore, as temperature augments, the rate of eliminating with a chemical disinfectant augments. The $\mathrm{pH}$ could dictate the ionization of the disinfectant and the viability of the organism [5]. Most waterborne 
Table 3. Ct Values for chlorine inactivation of microorganisms in water (99\% demobilization $)^{a}[5]$.

\begin{tabular}{|c|c|c|c|}
\hline Organism & Temperature $\left({ }^{\circ} \mathrm{C}\right)$ & $\mathrm{pH}$ & $C t$ \\
\hline \multicolumn{4}{|l|}{ Bacteria } \\
\hline E. coli & 5 & 6.0 & 0.04 \\
\hline E. coli & 23 & 10.0 & 0.6 \\
\hline Legionella pneumophila & 20 & 7.7 & 1.1 \\
\hline M. avium (strain A5) & 23 & 7.0 & 106 \\
\hline M. avium (strain 1060) & 23 & 7.0 & 204 \\
\hline Helicobacter pylori & 5 & 6.0 & 0.12 \\
\hline \multicolumn{4}{|l|}{ Viruses } \\
\hline Polio 1 & 5 & 6.0 & 1.7 \\
\hline Echo 1 & 5 & 6.0 & 0.24 \\
\hline Echo 1 & 5 & 7.8 & 0.56 \\
\hline Echo 1 & 5 & 10.0 & 47.0 \\
\hline Coxsackie B5 & 5 & 7.8 & 2.16 \\
\hline Coxsackie B5 & 5 & 10.0 & 33.0 \\
\hline Adenovirus 40 & 5 & 7.0 & 0.15 \\
\hline \multicolumn{4}{|l|}{ Protozoa } \\
\hline G. lamblia cysts & 5 & 6.0 & $54-87$ \\
\hline G. lamblia cysts & 5 & 7.0 & $83-133$ \\
\hline G. lamblia cysts & 5 & 8.0 & $119-192$ \\
\hline Naegleria fowleri tropozoites & 25 & 7.5 & 6 \\
\hline$N$. fowleri cysts & 25 & 7.5 & 32.1 \\
\hline Encephalitozoon intestinalis spores & 5 & 7.0 & 39 \\
\hline C. parvum oocysts & $21-24$ & $7.5-7.6$ & $9740-11,300$ \\
\hline Toxoplasma gondii & 22 & 7.2 & $>133,920$ \\
\hline \multicolumn{4}{|l|}{ Fungi } \\
\hline Aspergillus fumigatus & 25 & 7.0 & 946 \\
\hline A. terrus & 25 & 7.0 & 1404 \\
\hline Penicillium citrirnum & 25 & 7.0 & 959 \\
\hline Cladosporium tenuissimum & 25 & 7.0 & 71 \\
\hline
\end{tabular}

${ }^{a}$ In buffered distilled water.

microorganisms are negatively impacted by $\mathrm{pH}$ degrees under 3 and over 10. In the case of halogens such as chlorine, $\mathrm{pH}$ regulates the quantity of $\mathrm{HOCl}$ (hypochlorous acid) and $\mathrm{OCl}^{-}$(hypochlorite) in solution (Figure 8). $\mathrm{HOCl}$ is more performant than $\mathrm{OCl}^{-}$in killing pathogens. With chlorine, the $C t$ augments with $\mathrm{pH}$. Adherence of organisms to surfaces or particulate matter in water like clays and organic detritus helps in the resistance of microorganisms to disinfection 


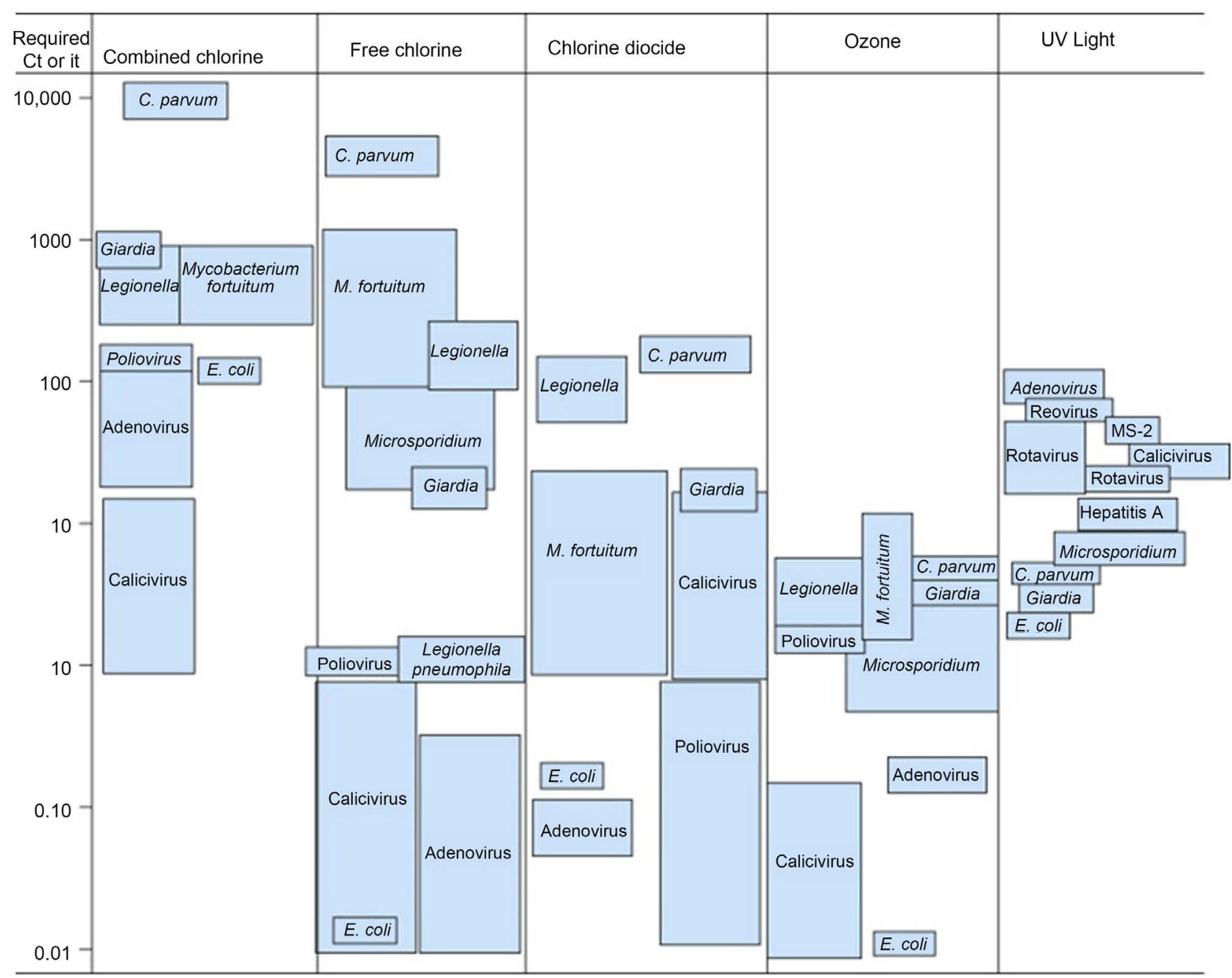

Figure 7. Overview of disinfection requirements for $99 \%$ demobilization of microorganisms. $C t=$ concentration of disinfectant $\times$ time. $I t=\left(\mu \mathrm{W} \cdot \mathrm{s} / \mathrm{cm}^{2}\right)($ time $)[5]$.

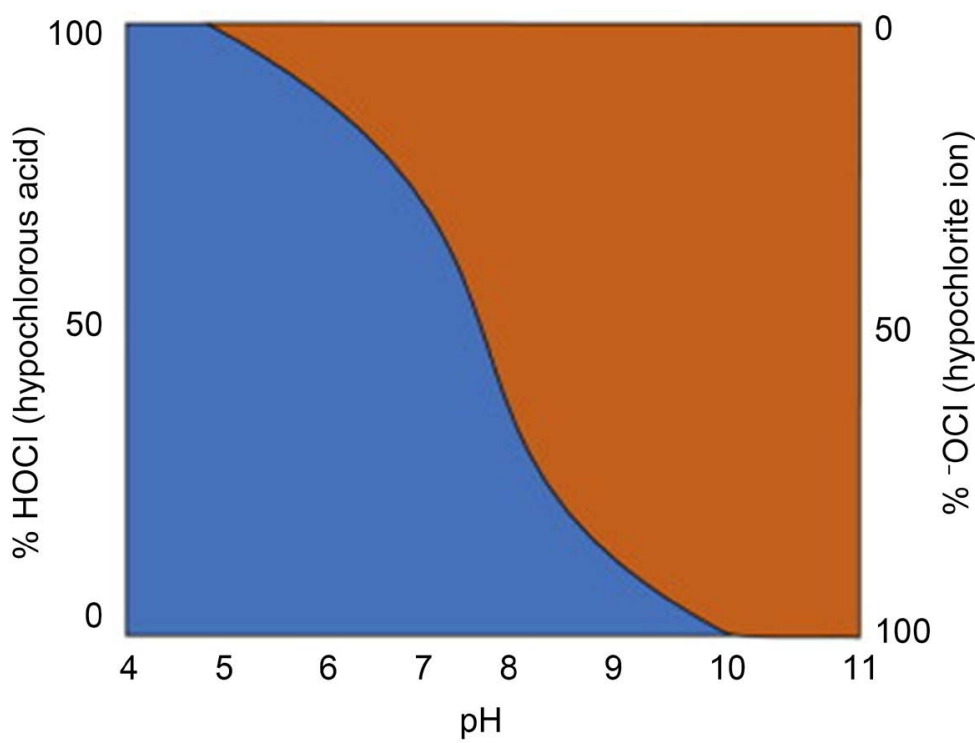

Figure 8. Distribution of $\mathrm{HOCl}$ and $\mathrm{OCl}^{-}$in water as a function of $\mathrm{pH}[5]$. 
[30] [31] [32]. Particulate matter may interfere by either acting chemically to react with the disinfectant, therefore negating the work of the disinfectant, or physically protecting the organism from the disinfectant [33] [34] [35]. The particulate-microbial complex may be thought of as: 1) adsorption of microbes to larger particles; 2) adsorption of small particles to the surface of the microbe; 3 ) encasement of the microbe by one or more large particles or many associated small particles [5] [36]-[41].

Disinfectant protection is increased by reducing the size of the organism and augmenting particle availability. Thus, viruses are accorded bigger protection than bacteria. For such causes, eliminating particulate or turbidity [42] in potable water treatment [43] [44] is obligatory to make certain the performance of disinfection in demolishing waterborne microbes [45] [46] [47] [48]. Dissolved chemical substances that disturb chemical disinfection comprise organic compounds, inorganic and organic nitrogenous compounds, iron, manganese and hydrogen sulfide [5] [49] [50] [51] [52].

Pathogenic and indicator bacteria appearing in the ecosystems could be more resistant to disinfectants than laboratory-grown bacteria [2] [3] [4]. Such resistance is cell-mediated and physiological in nature, needing that the organism develops adaptive qualities to survive below unfavorable ecological circumstances [33]. Cell-mediated pathways of resistance to disinfectant agents remain deficiently known juxtaposed with physicochemical protective impacts. Examples of cell-mediated resistance comprise: 1) polymer or capsule formation, which could lead to restricting the spread of the disinfectant into the cell;2) cellular aggregation, furnishing physical protection to internal cells; 3) cell wall and/or cell membrane modifications that conduct to decreased permeability to disinfectants; 4) alteration of sensitive sites, i.e., enzymes [33]; 5) efflux pumps to ameliorate reduction of the substance from the bacteria (like in the case of metals and some antibiotics); 6) generation of proteins to sequester metal ions [5].

It has been anticipated that numerous of such physiological events are depending on adaptation to low-nutrient circumstances in nature [5].

Regular subjection of bacteria and viruses to powerful oxidizing chemicals such as chlorine could lead to some selection for bigger resistance [53] [54]. Nevertheless, the ameliorated resistance is not big sufficiently to overpower levels of chlorine used in practice [5].

\subsection{Chlorine}

Chlorine and its compounds remain the most frequently employed disinfectants for dealing with potable and used water. Chlorine is a powerful oxidizing agent which, when introduced as gas to water, produces a mixture of hypochlorous acid ( $\mathrm{HOCl})$ and hydrochloric acids [5]:

$$
\mathrm{Cl}_{2}+\mathrm{H}_{2} \mathrm{O}=\mathrm{HOCl}+\mathrm{HCl}
$$

In dilute solutions, little $\mathrm{Cl}_{2}$ occurs in solution. The disinfectant's work is related to the $\mathrm{HOCl}$ produced. Hypochlorous acid dissociates as follows [5]: 


$$
\mathrm{HOCl}=\mathrm{H}^{+}+\mathrm{OCl}^{-}
$$

The ratio of hypochlorous acid and $\mathrm{OCl}^{-}$(hypochorite ion) is a function of the $\mathrm{pH}$ of the water (Figure 8). The quantity of $\mathrm{HOCl}$ is bigger at neutral and lower $\mathrm{pH}$ degrees, leading to bigger disinfection capability of chlorine at such $\mathrm{pH}$ degrees. Chlorine as $\mathrm{HOCl}$ or $\mathrm{OCl}^{-}$is known as free available chlorine. $\mathrm{HOCl}$ unites with ammonia and organic compounds to produce what is known as combined chlorine. The reactions of chlorine with ammonia and nitrogen-containing organic substances are of considerable significance in water disinfection. Such reactions conduct to the generation of monochloramine $\left(\mathrm{NH}_{2} \mathrm{Cl}\right)$, dichloramine $\left(\mathrm{NHCl}_{2}\right)$, trichloramine $\left(\mathrm{NCl}_{3}\right)$, etc. [5].

$$
\begin{array}{r}
\mathrm{NH}_{3}+\mathrm{HOCl} \rightarrow \mathrm{NH}_{2} \mathrm{Cl}+\mathrm{H}_{2} \mathrm{O} \\
\mathrm{NH}_{2} \mathrm{Cl}+\mathrm{HOCl} \rightarrow \mathrm{NHCl}_{2}+\mathrm{H}_{2} \mathrm{O} \\
\mathrm{NHCl}_{2}+\mathrm{HOCl} \rightarrow \mathrm{NCl}_{3}+\mathrm{H}_{2} \mathrm{O}
\end{array}
$$

Such chemicals kkep some disinfecting capacity of hypochlorous acid; however, they are much less efficient at a specific level than chlorine [5].

Free chlorine is very performant in demobilizing microorganisms [55] [56] [57] [58]. In potable water treatment [59]-[64], $1 \mathrm{mg} / \mathrm{L}$ or less for around $30 \mathrm{~min}$ is usually satisfactory to diminish considerably bacterial numbers. The occurrence of interfering substances in wastewater [65] [66] decreases the disinfection effectiveness of chlorine and comparatively elevated levels of chlorine (20 - 40 $\mathrm{mg} / \mathrm{L}$ ) become needed [67]-[72]. Enteric viruses and protozoan parasites stay more resistant to chlorine than bacteria (Table 3 ) and could be observed in secondary wastewater effluents after usual disinfection applications. Cryptosporidium and Toxoplasma oocysts remain so resistant to chlorine. A chlorine dosage of $100 \mathrm{mg} / \mathrm{L}$ is requested to induce $99 \%$ demobilization of Cryptosporidium following a 100-minute contact time (Table 3). Chloramines are much less efficacious than free chlorine (around 50 times less efficient) in demobilizing viruses [5].

As a powerful oxidizing agent, chlorine could react with any organic matter comprising proteins, lipids, carbohydrates, and nucleic acids to damage their structure. Bacterial demobilization via chlorine can lead to [33]: 1) modified permeability of the outer cellular membrane, conducting to infiltration of critical cell components; 2) interference with cell-associated membrane functions (such as phosphorylation of high-energy compounds); 3 ) impairment of enzyme and protein function as a consequence of the irreversible binding of the sulfyhydryl groups; 4) nucleic acid denaturation [5].

The real pathway of chlorine demobilization could implicate an integration of such steps or just the influence of chlorine on a few crucial sites. It seems that bacterial demobilization via chlorine is mostly provoked via the decay of physiological functions related to the bacterial cell membrane [5].

Chlorine can demobilize viruses through interaction with the viral capsid proteins or/and the nucleic acid (Figure 9) [5]. The site of action may also rely on the injection of chlorine and the sort of virus. It has been noted that at free 


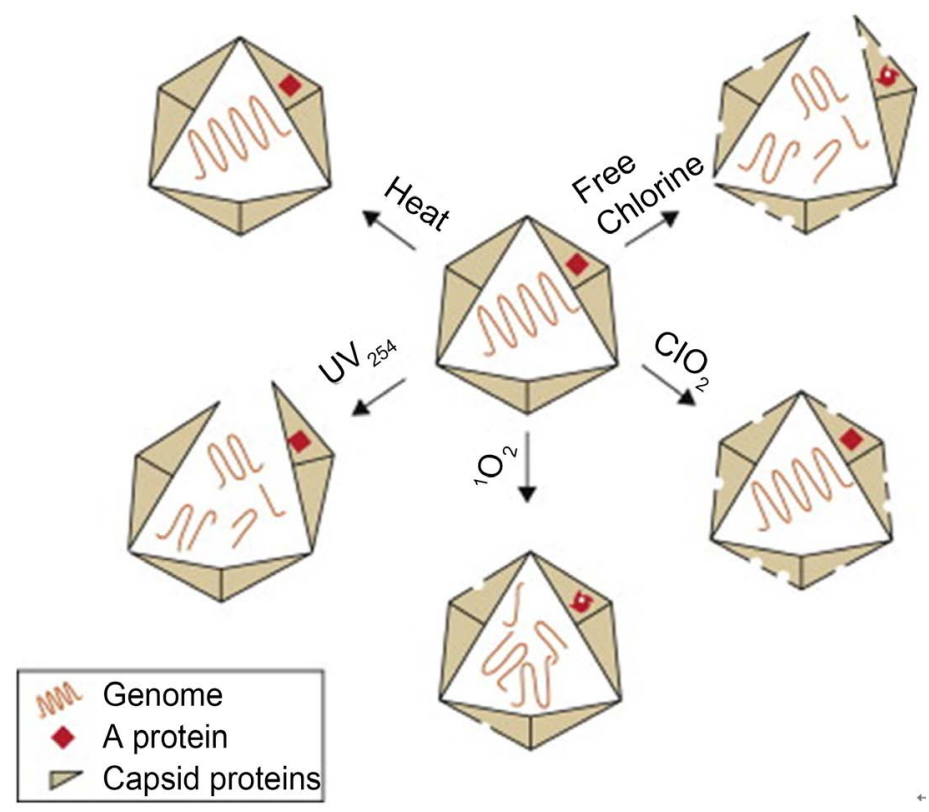

Figure 9. Pathways of MS2 virus demobilization via disinfectants [75].

chlorine dosages of less than $0.8 \mathrm{mg} / \mathrm{L}$, demobilization of poliovirus RNA happens without big structural alterations; however, chlorine injections in excess of $0.8 \mathrm{mg} / \mathrm{L}$ conduct to harm to the viral RNA and protein capsid (Figure 10) [73]. The protein coat seems to be the objective of the double-stranded RNA rotaviruses [74]. The protein implicated in the binding to the host bacterium was observed to be involved with the loss of infectivity in MS2 phage (Figure 11) [75].

\subsection{Ozone}

Ozone $\left(\mathrm{O}_{3}\right)$, a strong oxidizing agent, could be formed via passing an electric discharge through a stream of air or oxygen [76]. Ozone stays more costly than chlorine to implement in potable water treatment; however, it has augmented in popularity as a disinfectant since it does not generate trihalomethanes or other chlorinated by-products [77]-[82], which are found carcinogens. Nevertheless, aldehydes and bromates could be generated via ozonation and can possess unwanted health impacts. As ozone does not abandon any remaining in the water, ozone application is frequently pursued via chlorination. This is required to avoid regrowth of bacteria since the ozone breaks down complex organic compounds existing in water [83]-[87], into simpler ones that serve as substrates for growth in the water distribution system. The performance of ozone as a disinfectant is not affected via $\mathrm{pH}$ and ammonia [5].

Ozone is a much more powerful oxidant than chlorine (Table 3 and Table 4). The $C t$ estimates for $99 \%$ inactivation are only $0.0011-0.2$ for enteric bacteria and $0.04-0.42$ for enteric viruses [67]. Ozone seems to demobilize microbes via the identical routes as chlorine-founded disinfection: via disruption of membrane permeability [33] (Figure 9); impairment of enzyme function and/or protein integrity by oxidation of sulfyhydryl groups; and nucleic acid denaturation. 


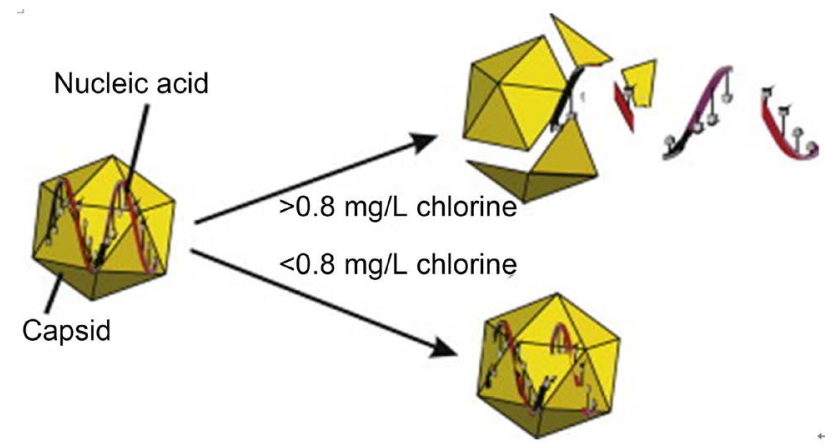

Figure 10. Virus demobilization via chlorine [5].

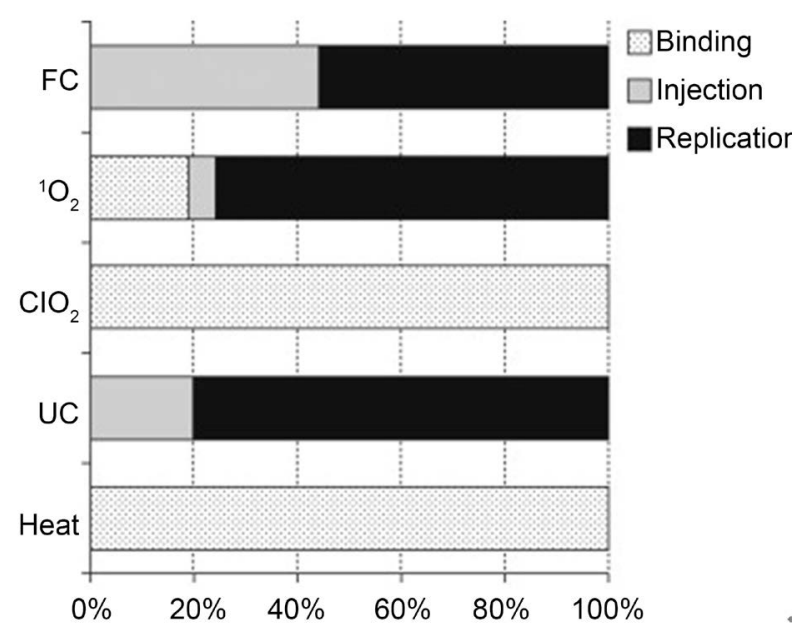

Figure 11. Relative contributions of MS2 host binding protein, nucleic acid injection and replication to overall inactivation by different disinfectants [75].

Table 4. $C t$ values for ozone inactivation of microorganisms in water (99\% demobilization) [5].

\begin{tabular}{cccc}
\hline Organism & Temperature $\left({ }^{\circ} \mathrm{C}\right)$ & $\mathrm{pH}$ & $C t$ \\
\hline Bacteria & & & $0.006-0.02$ \\
E. coli & 1 & 7.2 & \\
Viruses & 5 & 7.2 & 0.2 \\
Polio 1 & 25 & 7.2 & 0.72 \\
Polio 2 & 4 & $6.0-8.0$ & $0.019-0.064$ \\
Rota SA11 & 20 & 7.2 & $0.64-2.6$ \\
Coxsackie B5 & $5-7$ & 7.0 & 0.02 \\
Adeno 40 & & & 1.94 \\
Protozoa & 5 & 7.0 & 0.53 \\
Giardia muris & 5 & 7.0 & $0.30-0.04$ \\
G. lamblia & 5 & 7.0 & 40.0 \\
E. intestinalis & 1 & - & 7.0 \\
C. parvum & 7 & - & 3.5 \\
C. parvum & 22 & - & $>69$ \\
C. parvum & 20 & $7.7-7.8$ & \\
T. gondii & & & \\
& & &
\end{tabular}


The effect of ozone on destruction of the cell wall of bacteria and protozoan oocysts is dramatic (Figure 12 and Figure 13). Cryptosporidium oocysts could be demobilzed by ozone; however, a $C t$ of $1-3$ is requested. Viral demobilization can take place via breakup of the capsid proteins into subunits, resulting in release of the RNA, which may then be damaged (Figure 10).

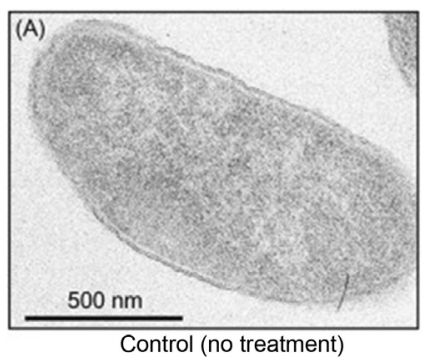

Control (no treatment)

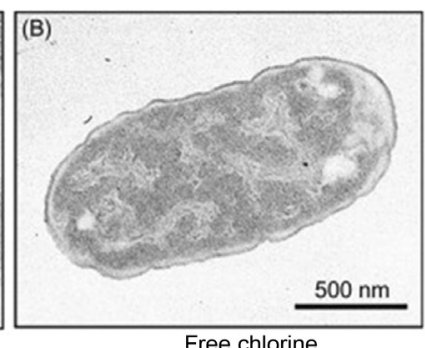

Free chlorine

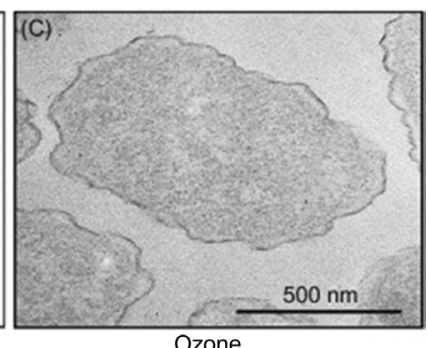

Ozone

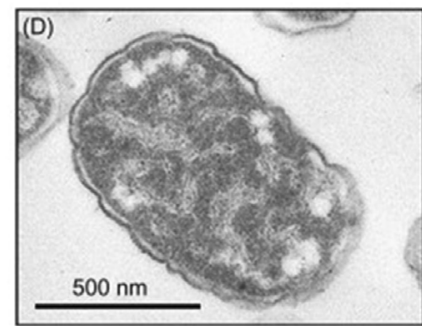

Chlorine dioxide

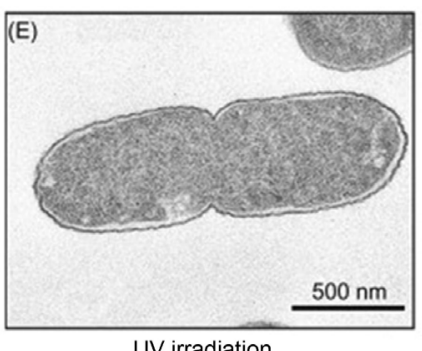

UV irradiation

Figure 12. Transmission electron micrographs of $E$. coli before and after $90 \%$ inactivation by various disinfectants [88].
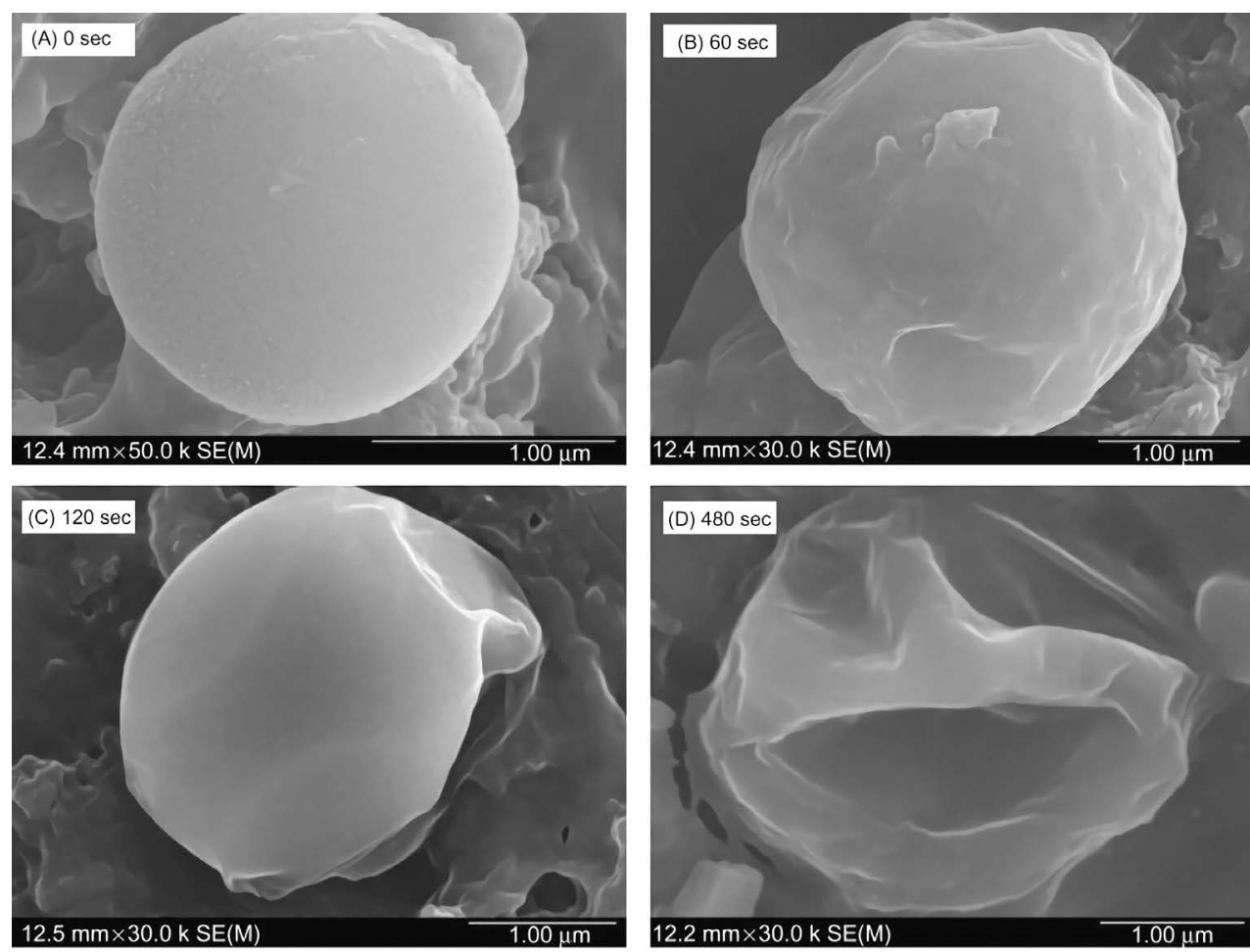

Figure 13. Scanning electron micrographs of Cryptosporidium oocysts after various time exposures to ozone [89]. 


\section{Securing Viruses Removal via Advanced Water Treatment Processes}

For drinking reuse, purifying wastewater needs the removal of enteric viruses to degrees that present no hazard to human health [11] [47] [49] [62] [65] [66] [90]. Advanced water treatment trains (such as chemical clarification [91] [92] [93] [94], reverse osmosis [95] [96], ultrafiltration [97] [98] [99] [100], advanced oxidation [12] [13] [40]) have been suggested to guarantee removals of viruses to differing degrees of regulatory control following the degrees of human subjection and related health hazards [47] [90]. In any evaluation, significance remains in detail on the level and sorts of viruses in the untreated wastewater, as well as the extent of reduction by each treatment method. Nevertheless, it is crucial that the uncertainty related to virus level and reduction or demobilization through wastewater treatment be comprehended to enhance such values and defining research requests. Gerba et al. [90] discussed the literature to try to define uncertainty in such values. Biological diversity inside families and genera of viruses (like enteroviruses, rotaviruses, adenoviruses, reoviruses, noroviruses) and particular virus kinds (such as serotypes or genotypes) forms the biggest uncertainty. Such features touch the procedures for the detection and quantification of viruses and predicted elimination performance via treatment technologies. To decrease the uncertainty, some strategies may be suggested; 1) inclusion of a virus indicator for assessing the efficiency of virus concentration and detection by molecular methods for each sample, 2) use of viruses most resistant to individual treatment processes (e.g. adenoviruses for UV light disinfection and reoviruses for chlorination), 3) data on ratio of virion or genome copies to infectivity in untreated wastewater, and 4) assessment of virus removal at field scale treatment systems to verify laboratory and pilot plant data for virus removal.

Hepatitis E Virus (HEV) is a prime reason for waterborne outbreaks in areas with poor sanitation. Since secure water supplies are the keystone for avoiding HEV outbreaks, details on the effectiveness of disinfection techniques are required. Guerrero-Latorre et al. [101] assessed the capacity of UV radiation [102] and flocculation-chlorination sachets (FCSs) to decrease HEV in water matrices. The HEV-p6-Kernow strain was replicated in the HepG2/C3A cell line, and they quantified genome numbers employing qRT-PCR and infectivity utilizing an immunofluorescence assay. UV irradiation trials employing low-pressure radiation depicted demobilization kinetics for HEV of $99.99 \%$ with a UV fluence of $232 \mathrm{~J} / \mathrm{m}^{2}$ (IC 95\%, 195.02 - 269.18). Further, the FCSs preparations importantly decreased viral levels in both water matrices.

Conventional water treatment plants follow multiple treatments to consecutively treat raw water for securing drinking water [103]. However, emerging issues (like an inferior reduction of emerging contaminants) [2] [3] [4] [49] defy the traditional treatment train [47]. Zhang et al. [104] realized bench-scale experiments with real surface waters to estimate ferrate(VI) treatment [38] [57] as a fundamental alternative technique for classical water treatment (Figure 14). In 

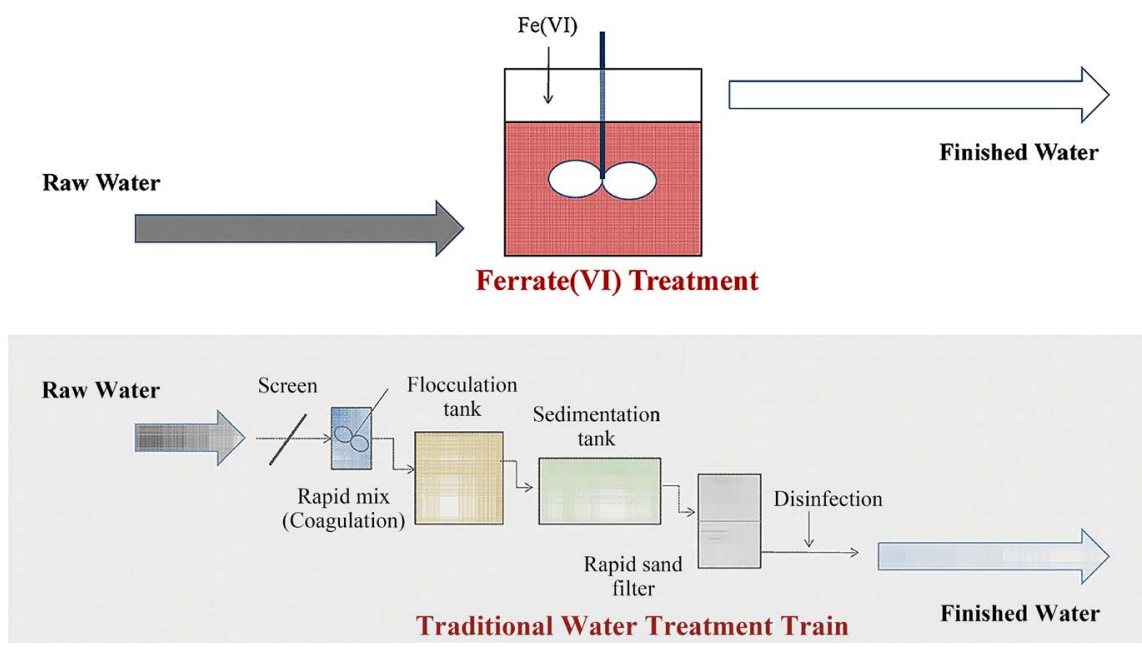

Figure 14. One-step ferrate(VI) treatment vs. alternative drinking water treatment [104].

fact, most previous researches on ferrate(VI) for treating water employed ferrate(VI) only for pre- or post-treatment or just as a disinfecting chemical. They focused on evaluating if one-step ferrate(VI) addition, integrated with sedimentation, provided a comprehensive treatment, better than or equivalent to traditional surface water treatment. They depicted that ferrate(VI) can at one and efficiently eliminate turbidity, decompose natural organic matter (NOM) [85] [105], and demobilize bacterial indicators in one sole injection. The treatment effectiveness depended excessively on ferrate(VI) dosage and $\mathrm{pH}$. As a rule, bigger ferrate(VI) injection enhanced the technology findings, except that it might re-suspend particles at a high injection at an alkaline circumstance. Lower $\mathrm{pH}$ promoted coagulation thanks to decreasing zeta potentials [94] on the particle surface and amelioration of their aggregation and improved the decomposition of NOM due to higher $\mathrm{Fe}(\mathrm{VI})$ reactivity toward reductive moieties. On the other hand, higher $\mathrm{pH}$ benefited the disinfection performance because of better stability and bigger subjection of ferrate(VI). Ferrate(VI) application could serve as a core treatment process in alternative water treatment designs for addressing various dares.

Rising water treatment techniques using ferrous and zero-valent iron [106] [107] [108] [109] depict encouraging virus alleviation via both demobilization and adsorption. Heffron et al. [110] tested iron electrocoagulation (EC) [6] [10] [15] [17] [18] [28] [31] [32] [34] [35] [36] [39] [80] for virus reduction in potable water via bench-scale batch trials. Proportional roles of physical reduction and demobilization, as evaluated via recovery via $\mathrm{pH} 9.5$ beef broth elution, were studied for three mammalian viruses (adenovirus, echovirus, and feline calicivirus) and four bacteriophage surrogates (fr, MS2, P22, and FX174). Even so, no one bacteriophage accurately represented the reduction of the mammalian viruses in all water matrices, bacteriophage FX174 was the only surrogate that depicted overall removal comparable to that of the mammalian viruses. Bacteriophages fr, MS2, and P22 were all more liable to demobilization than the three mammalian viruses, raising worries about the suitability of such frequent surro- 
gates as indicators of virus reduction. To discover why some bacteriophages were very vulnerable to demobilization, they studied the routes of bacteriophage reduction due to EC. Physical elimination was mainly attributed to the embodiment in flocs [58], whilst demobilization was firstly related to ferrous iron oxidation. Greater electrostatic attraction, virus aggregation, and capsid durability were suggested as causes for virus vulnerability to ferrous-based demobilization. Such findings propose that overall treatment claims founded on bacteriophage reduction for any iron-based technique have to be critically adopted because of the higher vulnerability of bacteriophages to demobilization via ferrous oxidation.

\section{Conclusions}

From this work, the main conclusions emerge:

1) Improved endeavors are requested to better quantify and account for uncertainties with the elimination/demobilization of viruses via treatment techniques optimized for ensuring purified water. This is crucial to better secure public confidence that hazard targets are satisfied and human health is preserved. Until such uncertainties are completely handled related to viral detection/elimination, it is judicious to employ RT-qPCR viral data in microbial risk assessments as documented for norovirus [90]. Dose-response models that account for virus aggregation and non-aggregation are also recommended.

2) Precise estimates of viral demobilization and log removal throughout water treatment techniques stay crucial for evaluating danger to human health, developing regulations, and informing engineering design of full-scale treatment plants. Practical demobilization details developed at bench-scale for human pathogens like norovirus and COVID-19 will be vital. With a convenient focus dedicated to the choice of optimal viral preparation procedures in seeded water treatment researches, the quality of information that will inform water treatment and reuse implementations will be ameliorated [103].

3) The more we study the composition of viruses and their behavior in nature and water and wastewater treatment industry, and the more we try the engineering methods for its disposal in water treatment plants, the more we realize that it is difficult to get rid of them using a single treatment method. Employing advanced water treatment trains (such as chemical clarification, reverse osmosis, ultrafiltration, advanced oxidation) was proposed to guarantee removals of viruses to differing degrees of regulatory control following the degrees of human subjection and related health hazards.

\section{Acknowledgements}

This research has been funded by the Research Deanship of University of Ha'il, Saudi Arabia, through the Project RG-191190.

\section{Conflicts of Interest}

The authors declare no conflicts of interest regarding the publication of this paper. 


\section{References}

[1] Strauss, J.H. and Strauss, E.G. (2008) Viruses and Human Disease. 2nd Edition, Elsevier, Amsterdam.

[2] Ghernaout, D. and Elboughdiri, N. (2020) Antibiotics Resistance in Water Mediums: Background, Facts, and Trends. Applied Engineering, 4, 1-6.

https://doi.org/10.4236/oalib.1106003

[3] Ghernaout, D. and Elboughdiri, N. (2020) Removing Antibiotic-Resistant Bacteria (ARB) Carrying Genes (ARGs): Challenges and Future Trends. Open Access Library Journal, 7, e6003. https://doi.org/10.4236/oalib.1106003

[4] Ghernaout, D. and Elboughdiri, N. (2020) Should We Forbid the Consumption of Antibiotics to Stop the Spread of Resistances in Nature? Open Access Library Journal, 7, e6138.

[5] Gerba, C.P. (2015) Disinfection (Ch. 29). In: Pepper, I.L., Gerba, C.P. and Gentry, T.J., Eds., Environmental Microbiology, 3rd Edition, Academic Press, Elsevier Inc., Amsterdam. https://doi.org/10.1016/B978-0-12-394626-3.00001-6

[6] Ghernaout, D. (2019) Virus Removal by Electrocoagulation and Electrooxidation: New Findings and Future Trends. Journal of Environmental Science and Allied Research, 85-90.

[7] Ghernaout, D. and Ghernaout, B. (2010) From Chemical Disinfection to Electrodisinfection: The Obligatory Itinerary? Desalination and Water Treatment, 16, 156-175. https://doi.org/10.5004/dwt.2010.1085

[8] Ghernaout, D., Benblidia, C. and Khemici, F. (2015) Microalgae Removal from Ghrib Dam (Ain Defla, Algeria) Water by Electroflotation Using Stainless Steel Electrodes. Desalination and Water Treatment, 54, 3328-3337.

https://doi.org/10.1080/19443994.2014.907749

[9] Kellali, Y. and Ghernaout, D. (2019) Physicochemical and Algal Study of Three Dams (Algeria) and Removal of Microalgae by Enhanced Coagulation. Applied Engineering, 3, 56-64.

[10] Ghernaout, D. (2019) Electrocoagulation Process for Microalgal Biotechnology-A Review. Applied Engineering, 3, 85-94.

[11] Ghernaout, D. and Elboughdiri, N. (2020) UV-C/ $/ \mathrm{H}_{2} \mathrm{O}_{2}$ and Sunlight $/ \mathrm{H}_{2} \mathrm{O}_{2}$ in the Core of the Best Available Technologies for Dealing with Present Dares in Domestic Wastewater Reuse. Open Access Library Journal, 7, e6161. https://doi.org/10.4236/oalib.1106161

[12] Ghernaout, D. (2013) Advanced Oxidation Phenomena in Electrocoagulation Process: A Myth or a Reality? Desalination and Water Treatment, 51, 7536-7554. https://doi.org/10.1080/19443994.2013.792520

[13] Ghernaout, D. and Elboughdiri, N. (2020) Advanced Oxidation Processes for Wastewater Treatment: Facts and Future Trends. Open Access Library Journal, 7, e6139.

[14] Block, S.S. (1991) Disinfection, Sterilization, and Preservation. 4th Edition, Lea \& Febiger, Philadelphia.

[15] Ghernaout, D., Badis, A., Ghernaout, B. and Kellil, A. (2008) Application of Electrocoagulation in Escherichia coli Culture and Two Surface Waters. Desalination, 219, 118-125. https://doi.org/10.1016/j.desal.2007.05.010

[16] Ghernaout, D., Badis, A., Braikia, G., Matâam, N., Fekhar, M., Ghernaout, B. and Boucherit, A. (2017) Enhanced Coagulation for Algae Removal in a Typical Algeria Water Treatment Plant. Environmental Engineering and Management Journal, 16, 
2303-2315. https://doi.org/10.30638/eemj.2017.238

[17] Belhout, D., Ghernaout, D., Djezzar-Douakh, S. and Kellil, A. (2010) Electrocoagulation of a Raw Water of Ghrib Dam (Algeria) in Batch Using Iron Electrodes. Desalination and Water Treatment, 16, 1-9. https://doi.org/10.5004/dwt.2010.1081

[18] Ghernaout, D. (2018) Electrocoagulation Process: Achievements and Green Perspectives. Colloid and Surface Science, 3, 1-5. https://doi.org/10.11648/j.css.20180301.11

[19] Ghernaout, D., Ghernaout, B. and Naceur, M.W. (2011) Embodying the Chemical Water Treatment in the Green Chemistry-A Review. Desalination, 271, 1-10. https://doi.org/10.1016/j.desal.2011.01.032

[20] Ghernaout, D. (2013) The Best Available Technology of Water/Wastewater Treatment and Seawater Desalination: Simulation of the Open Sky Seawater Distillation. Green and Sustainable Chemistry, 3, 68-88. https://doi.org/10.4236/gsc.2013.32012

[21] Ghernaout, D. (2017) Environmental Principles in the Holy Koran and the Sayings of the Prophet Muhammad. American Journal of Environmental Protection, 6, 75-79. https://doi.org/10.11648/j.ajep.20170603.13

[22] Ghernaout, D. (2018) Magnetic Field Generation in the Water Treatment Perspectives: An Overview. International Journal of Advances in Applied Sciences, 5, 193-203. https://doi.org/10.21833/ijaas.2018.01.025

[23] Jay, J.M. (1996) Modern Food Microbiology. 5th Edition, Chapman \& Hall, New York. https://doi.org/10.1007/978-1-4615-7473-6

[24] Eterpi, M., McDonnell, G. and Thomas, V. (2009) Disinfection against Parvoviruses. Journal of Hospital Infection, 73, 64-70. https://doi.org/10.1016/j.jhin.2009.05.016

[25] Liew, P. and Gerba, C.P. (1980) Thermo-Stabilization of Enteroviruses on Estuarine Sediment. Applied and Environmental Microbiology, 40, 305-308. https://doi.org/10.1128/AEM.40.2.305-308.1980

[26] Montgomery, J.M. (1988) Water Treatment and Design. John Wiley \& Sons, New York.

[27] Ghernaout, D. (2017) Microorganisms' Electrochemical Disinfection Phenomena. EC Microbiology, 9, 160-169.

[28] Ghernaout, D., Touahmia, M. and Aichouni, M. (2019) Disinfecting Water: Electrocoagulation as an Efficient Process. Applied Engineering, 3, 1-12.

[29] Ghernaout, D., Aichouni, M. and Touahmia, M. (2019) Mechanistic Insight into Disinfection by Electrocoagulation-A Review. Desalination and Water Treatment, 141, 68-81. https://doi.org/10.5004/dwt.2019.23457

[30] Ghernaout, D., Alghamdi, A. and Ghernaout, B. (2019) Microorganisms' Killing: Chemical Disinfection vs. Electrodisinfection. Applied Engineering, 3, 13-19.

[31] Ghernaout, D. (2019) Greening Electrocoagulation Process for Disinfecting Water. Applied Engineering, 3, 27-31.

[32] Ghernaout, D. (2019) Electrocoagulation and Electrooxidation for Disinfecting Water: New Breakthroughs and Implied Mechanisms. Applied Engineering, 3, 125-133.

[33] Stewart, M.W. and Olson, B.H. (1996) Bacterial Resistance to Potable Water Disinfectants. In: Modeling Disease Transmission and Its Prevention by Disinfection, Cambridge University Press, Cambridge, UK, 140-192.

[34] Ghernaout, D. and Elboughdiri, N. (2019) Electrocoagulation Process Intensification for Disinfecting Water-A Review. Applied Engineering, 3, 140-147. 
[35] Ghernaout, D. and Elboughdiri, N. (2019) Iron Electrocoagulation Process for Disinfecting Water-A Review. Applied Engineering, 3, 154-158.

[36] Ghernaout, D. (2019) Disinfection via Electrocoagulation Process: Implied Mechanisms and Future Tendencies. EC Microbiology, 15, 79-90.

[37] Ghernaout, D. and Elboughdiri, N. (2019) Mechanistic Insight into Disinfection Using Ferrate(VI). Open Access Library Journal, 6, e5946.

[38] Ghernaout, D. and Elboughdiri, N. (2019) Water Disinfection: Ferrate(VI) as the Greenest Chemical-A Review. Applied Engineering, 3, 171-180.

[39] Ghernaout, D. and Elboughdiri, N. (2020) Electrocoagulation Process in the Context of Disinfection Mechanism. Open Access Library Journal, 7, e6083.

[40] Ghernaout, D., Elboughdiri, N., Ghareba, S. and Salih, A. (2020) Electrochemical Advanced Oxidation Processes (EAOPs) for Disinfecting Water-Fresh Perspectives. Open Access Library Journal, 7, e6257. https://doi.org/10.4236/oalib.1106257

[41] Ghernaout, D., Elboughdiri, N., Ghareba, S. and Salih, A. (2020) Disinfecting Water with the Carbon Fiber-Based Flow-Through Electrode System (FES): Towards Axial Dispersion and Velocity Profile. Open Access Library Journal, 7, e6238. https://doi.org/10.4236/oalib.1106238

[42] Ghernaout, D., Ghernaout, B. and Boucherit, A. (2008) Effect of pH on Electrocoagulation of Bentonite Suspensions in Batch Using Iron Electrodes. Journal of Dispersion Science and Technology, 29, 1272-1275. https://doi.org/10.1080/01932690701857483

[43] Ghernaout, D. and Elboughdiri, N. (2020) Magnetic Field Application: An Underappreciated Outstanding Technology. Open Access Library Journal, 7, e6000.

[44] Ghernaout, D., Elboughdiri, N. and Alghamdi, A. (2019) Direct Potable Reuse: The Singapore NEWater Project as a Role Model. Open Access Library Journal, 6, e5980. https://doi.org/10.4236/oalib.1105980

[45] Ghernaout, D. and Elboughdiri, N. (2020) Electrochemical Technology for Wastewater Treatment: Dares and Trends. Open Access Library Journal, 7, e6020.

[46] Ghernaout, D., Elboughdiri, N. and Ghareba, S. (2020) Fenton Technology for Wastewater Treatment: Dares and Trends. Open Access Library Journal, 7, e6045. https://doi.org/10.4236/oalib.1106045

[47] Ghernaout, D. and Elboughdiri, N. (2020) On the Treatment Trains for Municipal Wastewater Reuse for Irrigation. Open Access Library Journal, 7, e6088.

[48] Ghernaout, D. and Elboughdiri, N. (2020) Domestic Wastewater Treatment: Difficulties and Reasons, and Prospective Solutions-China as an Example. Open Access Library Journal, 7, e6141.

[49] Ghernaout, D. and Elboughdiri, N. (2019) Water Reuse: Emerging Contaminants Elimination-Progress and Trends. Open Access Library Journal, 6, e5981.

[50] Ghernaout, D., Ghernaout, B., Saiba, A., Boucherit, A. and Kellil, A. (2009) Removal of Humic Acids by Continuous Electromagnetic Treatment Followed by Electrocoagulation in Batch Using Aluminium Electrodes. Desalination, 239, 295-308. https://doi.org/10.1016/j.desal.2008.04.001

[51] Ghernaout, D., Ghernaout, B., Boucherit, A., Naceur, M.W., Khelifa, A. and Kellil, A. (2009) Study on Mechanism of Electrocoagulation with Iron Electrodes in Idealised Conditions and Electrocoagulation of Humic Acids Solution in Batch Using Aluminium Electrodes. Desalination and Water Treatment, 8, 91-99. https://doi.org/10.5004/dwt.2009.668

[52] Saiba, A., Kourdali, S., Ghernaout, B. and Ghernaout, D. (2010) In Desalination, 
from 1987 to 2009, the Birth of a New Seawater Pretreatment Process: Electrocoagulation-An Overview. Desalination and Water Treatment, 16, 201-217. https://doi.org/10.5004/dwt.2010.1094

[53] Bates, R.C., Shaffer, P.T.B. and Sutherland, S.M. (1977) Development of Poliovirus Having Increased Resistance to Chlorine Inactivation. Applied and Environmental Microbiology, 33, 849-853. https://doi.org/10.1128/AEM.34.6.849-853.1977

[54] Haas, C.N. and Morrison, E.C. (1981) Repeated Exposure of Escherichia coli to Free Chlorine: Production of Strains Possessing Altered Sensitivity. Water, Air, \& Soil Pollution, 16, 233-242. https://doi.org/10.1007/BF01046857

[55] Ghernaout, B., Ghernaout, D. and Saiba, A. (2010) Algae and Cyanotoxins Removal by Coagulation/Flocculation: A Review. Desalination and Water Treatment, 20, 133-143. https://doi.org/10.5004/dwt.2010.1202

[56] Ghernaout, D., Mariche, A., Ghernaout, B. and Kellil, A. (2010) Electromagnetic Treatment-Bi-Electrocoagulation of Humic Acid in Continuous Mode Using Response Surface Method for Its Optimization and Application on Two Surface Waters. Desalination and Water Treatment, 22, 311-329.

https://doi.org/10.5004/dwt.2010.1120

[57] Ghernaout, D. and Naceur, M.W. (2011) Ferrate(VI): In Situ Generation and Water Treatment-A Review. Desalination and Water Treatment, 30, 319-332. https://doi.org/10.5004/dwt.2011.2217

[58] Ghernaout, D. and Ghernaout, B. (2012) Sweep Flocculation as a Second Form of Charge Neutralisation-A Review. Desalination and Water Treatment, 44, 15-28. https://doi.org/10.1080/19443994.2012.691699

[59] Ghernaout, D. and Ghernaout, B. (2012) On the Concept of the Future Drinking Water Treatment Plant: Algae Harvesting from the Algal Biomass for Biodiesel Production-A Review. Desalination and Water Treatment, 49, 1-18. https://doi.org/10.1080/19443994.2012.708191

[60] Ghernaout, D., Al-Ghonamy, A.I., Naceur, M.W., Ait Messaoudene, N. and Aichouni, M. (2014) Influence of Operating Parameters on Electrocoagulation of C.I. Disperse Yellow 3. Journal of Electrochemical Science and Engineering, 4, 271-283. https://doi.org/10.5599/jese.2014.0065

[61] Ghernaout, D., Al-Ghonamy, A.I., Irki, S., Grini, A., Naceur, M.W., Ait Messaoudene, N. and Aichouni, M. (2014) Decolourization of Bromophenol Blue by Electrocoagulation Process. Trends in Chemical Engineering, 15, 29-39.

[62] Ghernaout, D. (2017) Water Reuse (WR): The Ultimate and Vital Solution for Water Supply Issues. International Journal of Sustainable Development Research, 3, 36-46. https://doi.org/10.11648/j.ijsdr.20170304.12

[63] Ghernaout, D., Aichouni, M. and Alghamdi, A. (2018) Applying Big Data (BD) in Water Treatment Industry: A New Era of Advance. International Journal of Advances in Applied Sciences, 5, 89-97. https://doi.org/10.21833/ijaas.2018.03.013

[64] Djezzar, S., Ghernaout, D., Cherifi, H., Alghamdi, A., Ghernaout, B. and Aichouni, M. (2018) Conventional, Enhanced, and Alkaline Coagulation for Hard Ghrib Dam (Algeria) Water. World Journal of Applied Chemistry, 3, 41-55. https://doi.org/10.11648/j.wjac.20180302.12

[65] Ghernaout, D., Elboughdiri, N. and Al Arni, S. (2019) Water Reuse (WR): Dares, Restrictions, and Trends. Applied Engineering, 3, 159-170.

[66] Ghernaout, D., Elboughdiri, N. and Ghareba, S. (2019) Drinking Water Reuse: One-Step Closer to Overpassing the "Yuck Factor". Open Access Library Journal, 6, e5895. https://doi.org/10.4236/oalib.1105895 
[67] Bitton, G. (2011) Wastewater Microbiology. 4th Edition, Wiley-Liss, New York. https://doi.org/10.1002/9780470901243

[68] Ghernaout, D. (2018) Increasing Trends towards Drinking Water Reclamation from Treated Wastewater. World Journal of Applied Chemistry, 3, 1-9. https://doi.org/10.11648/j.wjac.20180301.11

[69] Ghernaout, D., Alshammari, Y. and Alghamdi, A. (2018) Improving Energetically Operational Procedures in Wastewater Treatment Plants. International Journal of Advances in Applied Sciences, 5, 64-72. https://doi.org/10.21833/ijaas.2018.09.010

[70] Al Arni, S., Amous, J. and Ghernaout, D. (2019) On the Perspective of Applying of a New Method for Wastewater Treatment Technology: Modification of the Third Traditional Stage with Two Units, One by Cultivating Microalgae and Another by Solar Vaporization. International Journal of Environmental Sciences \& Natural Resources, 16, 555934. https://doi.org/10.19080/IJESNR.2019.16.555934

[71] Ghernaout, D. (2019) Reviviscence of Biological Wastewater Treatment-A Review. Applied Engineering, 3, 46-55.

[72] Ghernaout, D. and Elboughdiri, N. (2019) Upgrading Wastewater Treatment Plant to Obtain Drinking Water. Open Access Library Journal, 6, e5959.

https://doi.org/10.4236/oalib.1105959

[73] Alvarez, M.E. and O’Brien, R.T. (1982) Effects of Chlorine Concentration on the Structure of Poliovirus. Applied and Environmental Microbiology, 43, 237-239.

https://doi.org/10.1128/AEM.43.1.237-239.1982

[74] Vaughn, J.M. and Novotny, J.F. (1991) Virus Inactivation by Disinfectants. In: Hurst, C.J., Ed., Modeling the Environmental Fate of Microorganisms, American Society for Microbiology, Washington, DC, 217-241.

[75] Wigginton, K.R., Pecson, B.M., Sigstam, T., Bosshard, F. and Kohn, T. (2012) Virus Inactivation Mechanisms: Impact of Disinfectants on Virus Function and Structural Integrity. Environmental Science \& Technology, 46, 12069-12078.

https://doi.org/10.1021/es3029473

[76] Ghernaout, D. and Elboughdiri, N. (2020) Towards Enhancing Ozone Diffusion for Water Disinfection-Short Notes. Open Access Library Journal, 7, e6253. https://doi.org/10.4236/oalib.1106253

[77] Boucherit, A., Moulay, S., Ghernaout, D., Al-Ghonamy, A.I., Ghernaout, B., Naceur, M.W., Ait Messaoudene, N., Aichouni, M., Mahjoubi, A.A. and Elboughdiri, N.A. (2015) New Trends in Disinfection By-Products Formation upon Water Treatment. Journal of Research \& Developments in Chemistry, 2015, Article ID 628833. https://doi.org/10.5171/2015.628833

[78] Ghernaout, D., Naceur, M.W. and Aouabed, A. (2011) On the Dependence of Chlorine By-Products Generated Species Formation of the Electrode Material and Applied Charge during Electrochemical Water Treatment. Desalination, 270, 9-22. https://doi.org/10.1016/j.desal.2011.01.010

[79] Ghernaout, D. (2018) Disinfection and DBPs Removal in Drinking Water Treatment: A Perspective for a Green Technology. International Journal of Advances in Applied Sciences, 5, 108-117. https://doi.org/10.21833/ijaas.2018.02.018

[80] Ghernaout, D. and Elboughdiri, N. (2020) Strategies for Reducing Disinfection By-Products Formation during Electrocoagulation. Open Access Library Journal, 7, e6076. https://doi.org/10.4236/oalib.1106076

[81] Ghernaout, D. and Elboughdiri, N. (2020) Disinfection By-Products: Presence and Elimination in Drinking Water. Open Access Library Journal, 7, e6140.

[82] Ghernaout, D. and Elboughdiri, N. (2020) Controlling Disinfection By-Products 
formation in Rainwater: Technologies and Trends. Open Access Library Journal, 7, e6162. https://doi.org/10.4236/oalib.1106162

[83] Ghernaout, D. and Elboughdiri, N. (2020) Eliminating Cyanobacteria and Controlling Algal Organic Matter-Short Notes. Open Access Library Journal, 7, e6252. https://doi.org/10.4236/oalib.1106252

[84] Ghernaout, D., Elboughdiri, N., Ghareba, S. and Salih, A. (2020) Coagulation Process for Removing Algae and Algal Organic Matter-An Overview. Open Access Library Journal, 7, e6272. https://doi.org/10.4236/oalib.1106272

[85] Ghernaout, D., Ghernaout, B. and Kellil, A. (2009) Natural Organic Matter Removal and Enhanced Coagulation as a Link between Coagulation and Electrocoagulation. Desalination and Water Treatment, 2, 203-222.

https://doi.org/10.5004/dwt.2009.116

[86] Ghernaout, D., Naceur, M.W. and Ghernaout, B. (2011) A review of Electrocoagulation as a Promising Coagulation Process for Improved Organic and Inorganic Matters Removal by Electrophoresis and Electroflotation. Desalination and Water Treatment, 28, 287-320. https://doi.org/10.5004/dwt.2011.1493

[87] Ghernaout, D. (2014) The Hydrophilic/Hydrophobic Ratio vs. Dissolved Organics Removal by Coagulation-A Review. Journal of King Saud University-Science, 26, 169-180. https://doi.org/10.1016/j.jksus.2013.09.005

[88] Choi, M., Kim, J., Kim, J.Y., Yoon, J. and Kim, J.H. (2010) Mechanisms of Escherichia coli Inactivation by Several Disinfectants. Water Research, 44, 3410-3418. https://doi.org/10.1016/j.watres.2010.03.017

[89] Ran, Z., Li, S., Huang, J., Yuan, Y., Cui, C. and Williams, C.D. (2010) Inactivation of Cryptosporidium by Ozone and Cell Ultrastructures. Journal of Environmental Sciences (China), 22, 1954-1959. https://doi.org/10.1016/S1001-0742(09)60345-4

[90] Gerba, C.P., Betancourt, W.Q., Kitajima, M. and Rock, C.M. (2018) Reducing Uncertainty in Estimating Virus Reduction by Advanced Water Treatment Processes. Water Research, 133, 282-288. https://doi.org/10.1016/j.watres.2018.01.044

[91] Ghernaout, D. (2017) Entropy in the Brownian Motion (BM) and Coagulation Background. Colloid and Surface Science, 2, 143-161.

[92] Ghernaout, D., Simoussa, A., Alghamdi, A., Ghernaout, B., Elboughdiri, N., Mahjoubi, A., Aichouni, M. and El-Wakil, A.E.A. (2018) Combining Lime Softening with Alum Coagulation for Hard Ghrib Dam Water Conventional Treatment. International Journal of Advances in Applied Sciences, 5, 61-70. https://doi.org/10.21833/ijaas.2018.05.008

[93] Ghernaout, D., Al-Ghonamy, A.I., Boucherit, A., Ghernaout, B., Naceur, M.W., Ait Messaoudene, N., Aichouni, M., Mahjoubi, A.A. and Elboughdiri, N.A. (2015) Brownian Motion and Coagulation Process. American Journal of Environmental Protection, 4, 1-15. https://doi.org/10.11648/j.ajeps.s.2015040501.11

[94] Ghernaout, D., Al-Ghonamy, A.I., Naceur, M.W., Boucherit, A., Messaoudene, N.A., Aichouni, M., Mahjoubi, A.A. and Elboughdiri, N.A. (2015) Controlling Coagulation Process: From Zeta Potential to Streaming Potential. American Journal of Environmental Protection, 4, 16-27. https://doi.org/10.11648/j.ajeps.s.2015040501.12

[95] Ghernaout, D. and El-Wakil, A. (2017) Requiring Reverse Osmosis Membranes Modifications-An Overview. American Journal of Chemical Engineering, 5, 81-88. https://doi.org/10.11648/j.ajche.20170504.15

[96] Ghernaout, D. (2017) Reverse Osmosis Process Membranes Modeling-A Historical Overview. Journal of Civil, Construction and Environmental Engineering, 2, 
$112-122$.

[97] Ghernaout, D., Alshammari, Y., Alghamdi, A., Aichouni, M., Touahmia, M. and Ait Messaoudene, N. (2018) Water Reuse: Extenuating Membrane Fouling in Membrane Processes. International Journal of Environmental Chemistry, 2, 1-12. https://doi.org/10.11648/j.ajche.20180602.12

[98] Ait Messaoudene, N., Naceur, M.W., Ghernaout, D., Alghamdi, A. and Aichouni, M. (2018) On the Validation Perspectives of the Proposed Novel Dimensionless Fouling Index. International Journal of Advances in Applied Sciences, 5, 116-122. https://doi.org/10.21833/ijaas.2018.07.014

[99] Ghernaout, D., El-Wakil, A., Alghamdi, A., Elboughdiri, N. and Mahjoubi, A. (2018) Membrane Post-Synthesis Modifications and How It Came about. International Journal of Advances in Applied Sciences, 5, 60-64.

https://doi.org/10.21833/ijaas.2018.02.010

[100] Ghernaout, D. (2019) Brine Recycling: Towards Membrane Processes as the Best Available Technology. Applied Engineering, 3, 71-84.

[101] Guerrero-Latorre, L., Gonzales-Gustavson, E., Hundesa, A., Sommer, R. and Rosina, G. (2016) UV Disinfection and Flocculation-Chlorination Sachets to Reduce Hepatitis E Virus in Drinking Water. International Journal of Hygiene and Environmental Health, 219, 405-411. https://doi.org/10.1016/j.ijheh.2016.04.002

[102] Schijven, J., Teunis, P., Suylen, T., Ketelaars, H., Hornstra, L. and Rutjes, S. (2019) QMRA of Adenovirus in Drinking Water at a Drinking Water Treatment Plant Using UV and Chlorine Dioxide Disinfection. Water Research, 158, 34-45. https://doi.org/10.1016/j.watres.2019.03.090

[103] Dunkin, N., Weng, S.C., Coulter, C.G., Jacangelo, J.G. and Schwab, K.J. (2018) Impacts of Virus Processing on Human Norovirus GI and GII Persistence during Disinfection of Municipal Secondary Wastewater Effluent. Water Research, 134, 1-12. https://doi.org/10.1016/j.watres.2018.01.053

[104] Zhang, H., Zheng, L., Li, Z., Pi, K. and Deng, Y. (2020) One-Step Ferrate(VI) Treatment as a Core Process for Alternative Drinking Water Treatment. Chemosphere, 242, 125134. https://doi.org/10.1016/j.chemosphere.2019.125134

[105] Ghernaout, D. and Boucherit, A. (2015) Review of Coagulation's Rapid Mixing for NOM Removal. Journal of Research \& Developments in Chemistry, 2015, Article ID: 926518. https://doi.org/10.5171/2015.926518

[106] Ghernaout, D. (2017) The Holy Koran Revelation: Iron Is a "Sent Down" Metal. American Journal of Environmental Protection, 6, 101-104. https://doi.org/10.11648/j.ajep.20170604.14

[107] Ghernaout, D., Irki, S. and Boucherit, A. (2014) Removal of $\mathrm{Cu}^{2+}$ and $\mathrm{Cd}^{2+}$, and Humic Acid and Phenol by Electrocoagulation Using Iron Electrodes. Desalination and Water Treatment, 52, 3256-3270. https://doi.org/10.1080/19443994.2013.852484

[108] Irki, S., Ghernaout, D. and Naceur, M.W. (2017) Decolourization of Methyl Orange (MO) by Electrocoagulation (EC) Using Iron Electrodes under a Magnetic Field (MF). Desalination and Water Treatment, 79, 368-377. https://doi.org/10.5004/dwt.2017.20797

[109] Irki, S., Ghernaout, D., Naceur, M.W., Alghamdi, A. and Aichouni, M. (2018) Decolorization of Methyl Orange (MO) by Electrocoagulation (EC) Using Iron Electrodes under a Magnetic Field (MF). II. Effect of Connection Mode. World Journal of Applied Chemistry, 3, 56-64. https://doi.org/10.11648/j.wjac.20180302.13 
[110] Heffron, J., McDermid, B., Maher, E., McNamara, P.J. and Mayer, B.K. (2019) Mechanisms of Virus Mitigation and Suitability of Bacteriophages as Surrogates in Drinking Water Treatment by Iron Electrocoagulation. Water Research, 163, 114877. https://doi.org/10.1016/j.watres.2019.114877 